\author{
SZYMON WIECZOREK \\ Instytut Historii \\ Uniwersytetu Rzeszowskiego
}

\title{
BONA STULTITIA. O ZNACZENIU PARADOKSÓW RETORYCZNYCH W NAJSTARSZYM ŻYWOCIE ŚW. WOJCIECHA
}

Mimo odległej metryki, godnych pamięci tradycji, a nawet poczynionych ostatnimi czasy postępów, badania nad językiem i stylistyką pierwszej biografii św. Wojciecha ${ }^{1}$ nie należą do specjalnie zaawansowanych ${ }^{2}$.

${ }^{1}$ Artykuł traktuje o tzw. cesarskiej (A) redakcji Vita prior. Odmienne lekcje późniejszych wersji utworu posłużyły głównie do badań nad recepcją pierwotnego tekstu. Podstawową cytowaną edycją pozostaje: S. Adalberti Pragensis episcopi et martyris vita prior, wyd. J. Karwasińska, Warszawa 1962, MPH n.s., t. 4, cz. 1 (dalej: VA I/A - s. 3-47; VA I/B - s. 51-67; VA I/C - s. 71-84; VA I, wstęp - s. V-XLVIII). Od Jadwigi Karwasińskiej pochodzą stosowane niżej oznaczenia wyodrębnionych przez nią redakcji i grup rękopisów oraz sygle tych ostatnich. Wzięto też pod uwagę brzmienie badanych ustępów Żywota w wydaniu Jürgena Hoffmanna, Vita Adalberti. Früheste Textüberlieferungen der Lebensgeschichte Adalberts von Prag, Essen 2005 (dalej: J. Hoffmann, VA). Uwzględnia ono lekcje niedostępnego J. Karwasińskiej podczas pracy nad edycją pasjonału akwizgrańskiego: Aachen, Domarchiv, G 9 (dalej: Aq). Niestety, ich wartość wydawca często przecenił (zob. w tej sprawie zwł. pracę Miłosza Sosnowskiego, cyt. niżej w przyp. 3). Najnowsza edycja Żywota opracowana przez Cristiana Gaşpara polega na ogół na tekście ustalonym przez Karwasińską, przynosi za to wiele nowych spostrzeżeń na temat erudycji hagiografa, The Life of Saint Adalbert Bishop of Prague and Martyr, wyd. i tłum. C. Gaşpar, w: Saints of the Christianization Age of Central Europe (Tenth-Eleventh Centuries) / Vitae sanctorum aetatis conversionis Europae centralis (saec. X-XI), red. G. Klaniczay, BudapestNew York 2013, s. 77-182 (dalej: C. Gaşpar, VA). Często stosowane skróty: BHL - Bibliotheca hagiographica latina antiquae et mediae aetatis, wyd. Socii Bollandiani, t. 1-2, Bruxellis 1898-1901, Novum Supplementum, wyd. H. Fros, Bruxelles 1986; CCh SL - Corpus Christianorum. Series Latina; CSEL - Corpus Scriptorum Ecclesiasticorum Latinorum; ŻW I (B. K.) - Jan Kanapariusz, Świętego Wojciecha Żywot pierwszy, tłum. B. Kürbis, w: W kręgu żywotów świętego Wojciecha, red. J. A. Spież, Tyniec-Kraków 1997, s. 41-77; ŻW I (K. A.) Jan Kanapariusz, Świętego Wojciecha Żywot pierwszy, tłum. K. Abgarowicz, w: Piśmiennictwo czasów Bolesława Chrobrego, oprac. J. Karwasińska, Warszawa 1966, s. 23-86.

${ }^{2}$ Zwracano już uwagę na niedostatek badań nad literacką warstwą wszystkich 
Trudno ten stan rzeczy konstatować bez zdziwienia. Zwłaszcza jeśli zważyć znaczenie podobnych studiów dla poznania umysłowości hagiografa, którego identyfikacja pozostaje wszak nadal przedmiotem sporu. Ponieważ we wznowionej nie tak dawno debacie nad atrybucją i proweniencją Żywota niemałą rolę odgrywają przesłanki z zakresu krytyki tekstu, wnikliwe rozpoznanie językowych właściwości utworu staje się nieomal nakazem chwili ${ }^{3}$. Jedną z takich charakterystycznych, a pozbawionych dotąd

żywotów św. Wojciecha, G. Labuda, Św. Wojciech w literaturze i legendzie średniowiecznej, w: Święty Wojciech $w$ polskiej tradycji historiograficznej, red. idem, Warszawa 1997, s. 212-226 (przedruk za: Święty Wojciech, 997-1947. Księga pamiątkowa, red. Z. Bernacki i in., Gniezno 1947, s. 89-112), tu s. 225; H. Fros, Wczesne żywoty św. Wojciecha. Stan i potrzeba badań, w: Środkowoeuropejskie dziedzictwo św. Wojciecha. Międzynarodowa konferencja naukowa, red. A. Barciak, Katowice 1998, s. 103-119, tu s. 117; J. Nechutová, Von Wenzel bis Adalbert: zwischen den Legenden, „Bohemia” 40, 1999, s. 54-64, tu s. 64. Ze starszych prac o języku i stylistyce Vita prior zob. m.in. A. Kolberg, Das Lobgedicht auf den heiligen Adalbert, „Zeitschrift für die Geschichte und Alterthumskunde Ermlands” 7, 1881, s. 79-112, 373-598, tu s. 96-105, 582 nn. (spostrzeżenia na kanwie wywodu o pierwszeństwie poematu Quattuor immensi - BHL 41, wobec którego Vita prior miałaby być wtórna); H. G. Voigt, Der Verfasser der römischen Vita des heiligen Adalbert. Eine Untersuchung mit Anmerkungen über die anderen ältesten Schriften über Adalbert, sowie einige strittige Punkte seiner Geschichte, Prag 1904, s. 25-31 i passim; M. Manitius, Geschichte der lateinischen Literatur des Mittelalters, t. 2, München 1923, s. 230; VA I, wstęp, s. XXXIVXXXVII; O. Králík, Filiace vojtěšských legend, Praha 1971, passim (również w związku z wywodami o pierwszeństwie Quattuor immensi). Z nowszych studiów zob. zwł. J. Starnawski, Drogi rozwojowe hagiografii polskiej i łacińskiej w wiekach średnich, Kraków 1993, s. 12-14; W. Berschin, Biographie und Epochenstil im lateinischen Mittelalter, t. 4, cz. 1, Stuttgart 1999, s. 161-168; C. Gaşpar, (Re)claiming Adalbert. Patristic Quotations and Their Function in Canaparius' Vita S. Adalberti, w: Promoting the Saints. Cults and Their Contexts from Late Antiquity until the Early Modern Period. Essays in Honor of Gábor Klaniczay for His 60th Birthday, red. O. Gecser i in., Budapest-New York 2011, s. 31-39.

${ }^{3}$ Nową odsłonę debaty nad genezą Vita prior zapoczątkował Johannes Fried, Gnesen - Aachen - Rom. Otto III. und der Kult des hl. Adalbert. Beobachtungen zum älteren Adalbertsleben, w: Polen und Deutschland vor 1000 Jahren. Die Berliner Tagung über den „Akt von Gnesen”, red. M. Borgolte, B. Scheller, Berlin 2002, s. 235-279 (kwestionując rzymską proweniencję dzieła i autorstwo Jana Kanapariusza, a także część tez J. Karwasińskiej w sprawie filiacji rękopisów, w tym istnienie starszej niż zachowane, awentyńskiej wersji utworu; zdaniem tego autora, pierwotna, tj. cesarska, redakcja spisana została w diecezji leodyjskiej przez tutejszego biskupa Notkera lub na jego polecenie). Jego tropem podążył J. Hoffmann, VA, passim. Z surową, ale nie zawsze wnikliwą krytyką tych teorii wystąpił Gerard Labuda, W sprawie autorstwa i miejsca napisania Żywotu pierwszego Świętego Wojciecha, St. Źr. 42, 2004, s. 115-130; idem, Święty Wojciech, biskup-męczennik, patron Polski, Czech i Węgier, wyd. 2, Wrocław 2004, s. 305 nn. Szerzej zakrojoną krytyczną analizę tez J. Frieda i J. Hoffmanna przeprowadził - na kanwie gruntowniejszych rozważań nad tradycją rękopiśmienną Żywota - M. Sosnowski, Studia nad wczesnymi żywotami św. Wojciecha - tradycja rękopiśmienna i polemika środowisk, Poznań 2013, s. 25-66, $197 \mathrm{nn}$. (piszący te słowa dziękuje autorowi za udostępnienie mu tej pracy przed jej publikacją). Uczony ten m.in. odrzuca istnienie awentyńskiego oryginału, uznaje za prawdopodobniejsze spisanie Vita prior na północ od Alp, ale broni tezy o wyższości Ls nad przekazami grupy mozańsko-reńskiej (Ib).Zob. też R. Michałowski, 
kompleksowego omówienia cech pisarskiego warsztatu twórcy Vita prior stanowi jego zamiłowanie do paradoksów ${ }^{4}$. Kimkolwiek był, najwyraźniej lubił zaskakiwać czytelników i słuchaczy pozornymi sprzecznościami, często w postaci lapidarnych oksymoronów, takich jak przywołana w tytule „dobra głupota”, „najpomyślniejsza przeciwność” czy „zwycięzca i zwyciężony"

Sama w sobie taka predylekcja może się wydać mało interesująca: żadne to w dziejach literatury novum. Podobne przejawy pisarskiej inwencji spotkać można już u autorów antycznych ${ }^{6}$. We wczesnośrednio-

Zjazd Gnieźnieński. Religijne przesłanki powstania arcybiskupstwa gnieźnieńskiego, Wrocław 2005, s. 116 n., przyp. 67; P. Kubín, Sedm přemyslovských kultů, Praha 2011, s. 169 n.; A. Pobóg-Lenartowicz, Najstaršie Životy sv. Vojtecha. Vitae s. Adalberti, w: Svätý Vojtech svätec, doba a kult, red. J. Nemeš, R. Kožiak i in., Bratislava 2011, s. 33-54; D. A. Sikorski, Kościół w Polsce za Mieszka I i Bolesława Chrobrego. Rozważania nad granicami poznania historycznego, Poznań 2011, s. 35 nn.; C. Gașpar, (Re)claiming, s. 34; idem, VA, s. 88-92 (ten ostatni broni tezy o autorstwie Kanapariusza i podziela pogląd o istnieniu zaginionego awentyńskiego oryginału, krytycznie oceniając edycję J. Hoffmanna).

${ }^{4}$ Literatura przedmiotu sygnalizuje problem w sposób dalece niepełny. Heinrich Gisbert Voigt (op. cit., s. 18 n., 26 n., 39) udokumentował fenomen szerszy jeszcze niż kwestia dyskutowana poniżej, mianowicie właściwa hagiografowi skłonność do „kontrastów i antytez". Upatrywał w tym podobieństwo do prozy Gerberta z Aurillac. W odnośnym zestawieniu wzmianek (ibidem, s. 26 nn.) uwzględnił kilka niewątpliwych retorycznych paradoksów. Zauważył też oksymoroniczny charakter wyrażenia „damna uictorie” (ibidem, s. 30). J. Karwasińska (VA I, wstęp, s. XXXVII) zidentyfikowała w Żywocie dwa tylko oksymorony: „,bona stultitia” i „prosperrima aduersitas”. Inni uczeni - w studiach o różnej tematyce i profilu - odnotowują z reguły pojedyncze przykłady podobnych retorycznych figur hagiografa. Np. Bernhard Askani (Das Bild Kaiser Ottos II. Die Beurteilung des Kaisers und seiner Regierung in der Geschichtsschreibung vom 10. Jh. bis zur Gegenwart, Heidelberg 1963, s. 26) zauważył „ocierające się o paradoksy" sformułowania w charakterystyce Ottona II: „uictor et uictus” i „damna uictorie”. Tym też wyrażeniom poświęcił więcej uwagi Walter Berschin, op. cit., s. 168.

${ }^{5} \mathrm{~W}$ złożoną naturę paradoksu jako zjawiska z pogranicza różnych dyscyplin wprowadza np. Roland Hagenbüchle, Was heißt „paradox”? Eine Standortbestimmung, w: Das Paradox. Eine Herausforderung des abendländischen Denkens, red. idem, P. Geyer, Tübingen 1992, s. 27-43. Por. też inne studia w tym tomie oraz M. Neumeyer, Paradoxe, das, w: Historisches Wörterbuch der Rhetorik, t. 6, red. G. Ueding i in., Tübingen 2003, kol. 516-524. Jako miarodajną dla poniższych rozważań wskazać można definicję (literackiego) paradoksu autorstwa Janusza Sławińskiego: „efektowne i zaskakujące swoją treścią sformułowanie, zawierające myśl skłóconą z powszechnie żywionymi przekonaniami, sprzeczną wewnętrznie, która jednak przynosi nieoczekiwaną prawdę", idem, Paradoks, w: idem, M. Głowiński i in., Słownik terminów literackich, wyd. 3, Wrocław-Warszawa-Kraków [1998], s. 370. Z punktu widzenia historii i teorii retoryki takie ujęcie może wzbudzać zastrzeżenia, por. H. F. Plett, Das Paradoxon als rhetorische Kategorie, w: Das Paradox, s. 89-104 (uczony wytyka podobnym, tradycyjnym definicjom m.in. brak precyzji i mieszanie kryteriów z zakresu retoryki, logiki, ontologii i epistemologii). Niniejsze studium traktuje jednak raczej o historii ludzkiej umysłowości, a nie tylko średniowiecznej retoryki.

${ }^{6}$ Zob. np. B. Gladigow, „Das Paradox macht Sinn”. Sinnkonstitution durch Paradoxien in 
wiecznej hagiografii paradoksy retoryczne zyskały sobie niemałą popularność. Wyrastały z języka pełnego antytetycznych przeciwstawień wyrażających właściwe religijnemu światopoglądowi autorów dychotomie, nade wszystko fundamentalną opozycję między tym, co boskie (duchowe i wieczne), a tym, co ziemskie (cielesne, materialne, przemijające) ${ }^{8}$. Demonstrując wyższość ducha nad ciałem ${ }^{9}$, hagiografowie raz po raz rzucali wyzwanie temu, co potocznie uchodzi za naturalną kolej rzeczy, przyrodzoną śmiertelnym kondycję czy powszechnie przyjęte reguły wnioskowania (zwane często „zdrowym” rozsądkiem). Czynili tak z zasady mocą samych opisywanych faktów (a więc np. sprzecznych z logiką tego świata cudów), ale wielu starało się zaakcentować owe „niemożliwości” także na płaszczyźnie językowej, siląc się na mniej lub bardziej wyrafinowane, retoryczne figury ${ }^{10}$. Twórca Vita prior był niewątpliwie dziedzicem tego sposobu myślenia i pisania, ale nie oznacza to, że jego paradoksy traktować należy jako przejaw bezrefleksyjnego konformizmu wobec literackiej tradycji. Niedostrzeżona do tej pory skala jego zabiegów, a bardziej jeszcze funkcje, jakie owe pozornie absurdalne konstatacje pełnią w Żywocie, każą podejrzewać, że dworując sobie tak uparcie ze „zdrowego" rozsądku odbiorców, troszczył się nie tylko o stylistyczne walory dzieła.

Niestety, nawet pilnie tropiąc językowe niuanse, nie sposób całkiem przezwyciężyć skutków wielowiekowego oddalenia. Precyzyjna identyfikacja tego, co w pojęciu średniowiecznego autora było (na pozór) nie do pomyślenia, sprawia dziś niekiedy kłopot. Próba wytyczenia granic owego nieprawdopodobieństwa czy sprzeczności konstytuującej paradoks pozostaje skażona nieusuwalną chyba dozą subiektywizmu. Innymi słowy, trudno czasem rozstrzygnać, czy nawykły do kontestacji doczes-

der griechischen Antike, w: Das Paradox, s. 195-208; E. Lefèvre, Die Bedeutung des Paradoxen in der römischen Literatur der frühen Kaiserzeit, „Poetica” 3, 1970, s. 59-82 (〈http://www. freidok.uni-freiburg.de/volltexte/4949/> [dostęp 22 VII 2013], urn:nbn:de:bsz:25-opus -49498); idem, Die Bedeutung des Paradoxen in der römischen Literatur, w: Das Paradox, s. 209-246; H. Kraft, Die Paradoxie in der Bibel und bei den Griechen als Voraussetzung für die Entfaltung der Glaubenslehren, w: Das Paradox, s. 247-272.

${ }^{7}$ Zob. zwł. M. van Uytfanghe, La formation du langage hagiographique en Occident latin, „Cassiodorus” 5, 1999, s. 143-169, tu s. 162 n., a także idem, Stylisation biblique et condition humaine dans l'hagiographie mérovingienne (600-750), Brussel 1987, s. 133 nn.

${ }^{8}$ M. van Uytfanghe, La formation, s. $158 \mathrm{nn}$. Zob. też A. Blaise, Manuel du latin chrétien, Strasbourg 1955, s. 30 nn.; M. van Uytfanghe, Stylisation, zwł. s. 133 nn. Por. S. Kwiatkowski, Neoplatońskie rozumienie natury człowieka $w$ duchowości benedyktyńskiej $w$ kręgu misjonarzy zachodniej Słowiańszczyzny na przełomie X i XI wieku, w: Ludzie, Kościót, wierzenia. Studia z dziejów kultury i społeczeństwa Europy Środkowej (średniowiecze - wczesna epoka nowożytna), red. W. Iwańczak, S. K. Kuczyński, Warszawa 2001, s. 29-36 (artykuł odwołuje się m.in. do treści Vita prior).

${ }_{9}^{9}$ Por. Rz 8,1 nn.; M. van Uytfanghe, Stylisation, s. 120.

${ }^{10}$ Zob. prace cyt. w przyp. 7. 
nych ograniczeń hagiograf zamierzył dane wyrażenie jako paradoks, czy $n^{1} \mathrm{e}^{11}$. Zasadną wydaje się więc powściągliwość i ograniczenie badań przynajmniej na początek - do przykładów stosunkowo w ich paradoksalnym wydźwięku ewidentnych, jak oksymorony przytoczone powyżej.

Najbardziej jednorodną formalnie, a zarazem stosunkowo liczną grupę paradoksów hagiografa stanowią sformułowania wyrosłe ze wspomnianego fundamentalnego konfliktu, powstałe z celowego połączenia pojęć reprezentujących dwie różne rzeczywistości i (lub) właściwe im, sprzeczne wzajemnie porządki wartości: wieczną sferę ducha (niebo) z jednej, a ulotną doczesność (ziemię) z drugiej strony. Nie wszyscy współcześni odczuwali tę opozycję równie radykalnie i dalece nie wszyscy zalecali pielgrzymującym do Królestwa Niebieskiego konsekwentną wzgardę czy nienawiść do materialnego świata ${ }^{12}$. Twórca Vita prior należał jednak do tych, którzy owe podziały kreślili grubą kreską: świętość oznaczała dlań nieustanną kontestację wyobrażeń, pragnień i postaw bliskich pospolitym śmiertelnikom odrzucenie czy wręcz odwrócenie właściwej im hierarchii wartości ${ }^{13}$.Pod piórem biografa Wojciech miał więc expressis verbis zachęcać Ottona III, by wzgardziwszy dobrami doczesnymi, łaknął wieczności, by miast ufać przemijającym, szukał tego, co trwałe ${ }^{14}$. Ów aksjologiczny dysonans hagiograf

${ }^{11}$ Por. np. ,Sic de die in diem semper nouus et se ipso robustior succrescens”, VA I/A, c. 20, s. 31 (wypowiedź wzorowana nota bene na jednym z listów Grzegorza Wielkiego, z nawiązaniem do 2 Sm 3,1, W. Berschin, op. cit., s. 165); „lęto clamore sua scelera laudantes", c. 30, s. 47. Por. też niżej przyp. 93.

${ }^{12}$ Zob. R. Michałowski, Prądy religijne w imperium ottońskim i ich polityczne implikacje, w: Polska na przełomie I i II tysiaclecia. Materiały sesji Stowarzyszenia Historyków Sztuki, Poznań, listopad 2000, red. S. Skibiński, Poznań 2001, s. 51-63; idem, Zjazd, s. 344 nn.; idem, Duchowość w X wieku, w: Tu się wszystko zaczęło. Rola Poznania w państwie Pierwszych Piastów, red. A. Wójtowicz, Poznań 2010, s. 61-81, tu s. 73 nn.

${ }^{13}$ Zob. S. Kwiatkowski, op. cit., zwł. s. 33. O modelu świętości w Vita prior por. m.in. J.W. Góra, Sylwetka biskupa w XII i XIII-wiecznej Polsce na podstawie kronik i żywotów świętych, „Studia Teologicznodogmatyczne” 4, 1984, s. 3-191, tu s. 103-127; W. Sieradzan, Modele religijności i świętości w żywotach św. Wojciecha X-XIII w. Studium porównawcze, „Ateneum Kapłańskie” 106, 1986, s. 442-454; P. Węcowski, Ideał świętości w najstarszych żywotach świętego Wojciecha, „Teka Historyka” 1997, 7, s. 3-15; A. Weiss, Wojciechowy model biskupa i chrześcijanina w świetle „Vita prior”, w: Dziedzictwo kultu Świętego Wojciecha, red. R. Knapiński, Lublin 1998, s. 29-39; F. Lotter, Adalbert von Prag in der Darstellung der zeitgenössischen Lebensbeschreibungen, w: Kirchengeschichtliche Probleme des Preussenlandes aus Mittelalter und früher Neuzeit, red. B. Jähnig, Marburg 2001, s. 11-52 (jest to poprawiona wersja artykułu: Das Bild des hl. Adalbert in der römischen und der sächsischen Vita, w: Adalbert von Prag. Brückenbauer zwischen dem Osten und Westen Europas, red. H. H. Henrix, Baden-Baden 1997, s. 77-107), tu zwł. s. 22, 35 n., 48 nn.

${ }^{14}$ VA I/A, c. 23, s. 35 (wypowiedź wzorowana na słowach Grzegorza Wielkiego, C. Gaşpar, VA, s. 161, przyp. 7). Por. np. R. Michałowski, Zjazd, s. 382 n. 
ujął jeszcze dosadniej, komplementując matkę bohatera, która - jak twierdził - „bardzo mało ceniła to, co głupi poczytują za najważniejsze”15. Samego świętego wysławiał m.in. słowami: „zadowalając się wszystkim co pospolite i najgorsze, im był większy, tym bardziej wobec wszystkich się uniżał, im bogatszy w skarby duchowe, tym bardziej pragnął w oczach ludzkich być małym, ubogim i wzgardzonym" 16 . 0 tym, że jego postępowanie stanowiło jaskrawe przeciwieństwo zachowań ogółu, przypominał niekiedy tak dobitnie, jakby chciał zakarbować tę prawdę w umysłach najmniej nawet bystrych odbiorców ${ }^{17}$.

Pierwsze oksymorony wspomnianego typu pojawiają się już w początkowych partiach utworu, w opowieści o chorobie małego Wojciecha. W myśl wyjaśnień autora wynikła ona z winy rodziców, którzy kierując się fizyczną urodą potomka, postanowili przeznaczyć mu karierę świecką ${ }^{18}$. Ich decyzję hagiograf kwalifikuje najpierw jako „pius error” 19 , a więc nie tyle może „pobożny”, ile raczej: „płynący z miłości błąd”20, by po chwili dodać inne, niecodzienne określenie: „mala

${ }^{15}$ ŻW I (K. A.), s. 27; VA I/A, c. 1, s. 4.

${ }^{16}$ ŻW I (K.A.), s. 63; VA I/A, c. 20, s. 31. Dostrzeżono zależność tej charakterystyki od Reguły św. Benedykta (np. VA I/A, s. 31, przyp. 118) i Dialogów Grzegorza Wielkiego (C. Gaşpar, VA, s. 151, przyp. 5). Trzeba też wskazać wyraźną inspirację biblijną: Syr 3,20.

${ }_{17}$ Zob. ,totus ardore martyrii flagrans [ie. Adalbertus] non tardiore desiderio et cursu, quam qui fugit hostem, sponte uenit in hostem", VA I/A, c. 19, s. 30. Repetycja słowa hostem poteguje kontrast.

${ }^{18}$ VA I/A, c. 2, s. 5.

19 "Quicquid autem pius error, uerum mala uenia parentum in hoc deliquid”, ibidem. W rękopisach Ll, Aq i $\mathrm{Rv}_{2}$,pius error" nie występuje, zdanie rozpoczyna się od słów: „Quicquid autem non solum error”, J. Hoffmann, VA, s. 33 (Aq, f. 103rb); VA I/A, c. 2, s. 5, przyp. 1 (ad v. pius). J. Fried, op. cit., s. 243, przyp. 36, i J. Hoffmann, VA, s. 65, 94 n., 127 (por. idem, Der Adalbertskult im Aachener Marienstift, „Deutsches Archiv für Erforschung des Mittelalters” 62, 2006, s. 607-617, tu s. 611 n.), uznali lekcje ,non solum" za lepszą. Tak też przyjął C. Gaşpar, VA, s. 98. Wedle J. Frieda, wskazuje na to słówko „verum” i fakt, że w postępku rodziców bohatera hagiograf upatruje ich "winę" (co uczony uważa najwyraźniej za trudne do pogodzenia z pozytywnymi konotacjami przymiotnika pius).J. Hoffmann sądzi, że połączenie „non solum” - „verum” ukazuje błąd rodziców Wojciecha jako bezpośredni skutek ich zachowania, tym samym mocniej akcentując ich odpowiedzialność. „Pius error” miałby być łagodniejszy w wymowie, a więc wtórny. Takie stanowisko wzbudziło już wątpliwości M. Sosnowskiego (op. cit., s. 44, przyp. 74), który słusznie zwrócił uwagę m.in. na wzajemny związek wyrażeń „pius error” i „mala uenia”. Za pierwszeństwem „miłosnego błędu” zdecydowanie przemawia też potwierdzone wieloma omówionymi niżej przykładami zamiłowanie hagiografa do podobnych retorycznych figur. Lekcja „non solum” to nic innego jak podjęta przez jednego z kopistów próba złagodzenia zbudowanego przez autora (a trafnie skądinąd dostrzeżonego przez J. Frieda) semantycznego napięcia między pius i uenia z jednej, a error, mala i culpa z drugiej strony. Por. VA I/B, c. 2, s. 51 (bez zmian); ,parentum error”, VA I/C, c. 2, s. 72.

${ }^{20}$ Por. ,godziwy błąd”, ŻW I (K.A.), s. 29 = ŻW I (B. K.), s. 42. 
uenia"21. Jego oksymoroniczną wymowę najwierniej oddaje dosłowne tłumaczenie: przeznaczając syna do spraw doczesnych, rodzice okazali mu w istocie „złą łaskę" czy też „złą życzliwość”22. Sformułowanie to razi, ale takie właśnie ma zadanie. Obydwa oksymorony realizują zaanonsowany schemat konstrukcyjny, powstały z połączenia kategorii reprezentujących odmienne porządki. Rozumującym „po ludzku” decyzja rodziców Wojciecha jawiła się jako akt miłości (stąd: pius), w porządku Boskim była jednak błędem (error). W oczach zwykłych śmiertelników, w tym także w przekonaniu Sławnika i jego małżonki, ich plany względem dziecka mogły uchodzić za oznakę przychylności (uenia), ale w kategoriach wiecznych - jako sprzeczne z wolą Stwórcy i szkodliwe z punktu widzenia zbawienia chłopca - winny być ocenione jako złe (mala) ${ }^{23}$. Stawiając oksymorony obok siebie i odnosząc je do wspólnego desygnatu (mowa o decyzji w sprawie przyszłości dziecka), hagiograf umiejętnie spiętrzył logiczny galimatias: błąd okazuje się w jednej chwili łaską, akt miłości - czymś złym $^{24}$. Sprzeczność jest jednak wyłącznie pozorna i nie może dziwić, że autor przypisuje rodzicom świętego winę (culpa). W jego oczach - co jasno wynika z treści anegdoty - dobre intencje nie stanowią bowiem usprawiedliwienia, nie zwalniają od odpowiedzialności ${ }^{25}$. Wina może być również skutkiem niewiedzy. Jest to pogląd o rodowodzie antycznym, znany np. z pism św. Hieronima ${ }^{26}$. Rodzice Wojciecha dokonali wyboru

${ }^{21}$ VA I/A, c. 2, s. 5. Tak też J. Hoffmann, VA, s. 33 (Aq, f. 103rb); VA I/B, c. 2, s. 51. Por. VA I/C, c. 2, s. 72 (oksymoron usunięty).

${ }^{22}$ Por. „złe upodobanie”, ŻW I (K. A.), s. 29 = ŻW I (B. K.), s. 42; „die schädliche Nachsicht", J. Hoffmann, VA, s. 160 (por. idem, Der junge Kaiser und der Heilige - Otto III. und die Anfänge des Adalbertskultes in Aachen, w: Krönungen. Könige in Aachen - Geschichte und Mythos, red. M. Kramp, t. 1, Mainz 2000, s. 295-301, tu s. 298 - sens wyrażenia oddany jako „Nachlässigkeit”); „inappropriate license”, C. Gaşpar, VA, s. 99.

${ }^{23}$ C. Gaşpar (idem, VA, s. 98 n., przyp. 7) uważa, że hagiograf wini rodziców świętego za uleganie ziemskiemu pięknu. Nie jest to pewne. Być może pobłądzili, ponieważ chcieli odebrać Bogu to, co jako najpiękniejsze, powinni Mu ofiarować.

${ }^{24}$ M. Sosnowski (op. cit., s. 44, przyp. 74) pisze o „efektownej grze przeciwieństw”.

${ }^{25}$ Jest to poniekąd zbieżne z etycznymi zapatrywaniami, których ślad dostrzegł w Żywocie (przypisując je samemu Wojciechowi) Roman Michałowski, Adalbert, Sylvestre II et l'Église de Pologne, w: Gerberto d'Aurillac da Abate di Bobbio a Papa dell'Anno 1000, red. F. G. Nuvolone, Bobbio 2001, s. 483-515, tu s. 489-492; idem, rec.: Gerard Labuda, Święty Wojciech biskup-męczennik, patron Polski, Czech i Węgier, Wrocław 2000, KH 109, 2002, 4, s. 136-141, tu s. 138. Por. S. Wieczorek, Święty porzuca biskupstwo, a biograf go thumaczy. Z badań nad warsztatem pisarskim twórcy „Vita prior sancti Adalberti”, w: Człowiek społeczeństwo - źródło. Studia dedykowane Profesor Jadwidze Hoff, red. S. Kozak i in., Rzeszów 2014, s. 445-462, tu s. 448, 457 nn.

${ }^{26}$ Zob. m.in. „quamquam uoluntas non sit in crimine, error in culpa est”, S. Eusebii Hieronymi Epistulae, wyd. I. Hilberg, wyd. 2, Vindobonae 1996, CSEL, t. 54-56, cz. 1, nr 22, c. 8,5 , s. 156; cz. 3, nr 140, c. 11, 2, s. 280. Por. S. Visintainer, La dottrina del peccato in s. Girolamo, Roma 1962, s. $85 \mathrm{nn}$. 
wedle aksjologii tego świata ${ }^{27}$, w opinii hagiografa zgrzeszyli więc brakiem religijnej świadomości. Sfera moralna i intelektualna okazują się ściśle powiązane: cnota nie może się obyć bez (właściwie pojętej) mądrości $^{28}$. Nic dziwnego, że ludzie przywiązani do ziemskich wartości nazwani zostali wcześniej „głupcami”.

„Mala uenia" stanowi trawestację popularnego u autorów klasycznych wyrażenia „(cum) bona uenia”29. Wydaje się jednak sformułowaniem rzadkim, zapewne oryginalnym pomysłem hagiografa ${ }^{30}$. „Pius error" był bardziej znany. Posługiwał się nim niejednokrotnie - byłbyż to przypadek? - właśnie św. Hieronim. W jednym z listów pisał nawet o „płynącym z miłości błędzie” w dość podobnym kontekście. Krytykując ojca adresatki niechętnego jej trwaniu we wdowieństwie, wprowadził znamienne rozróżnienie: nie odmawiał mu „miłości” (amor), lecz „rozeznania w miłości” (amoris scientia) ${ }^{31}$. Ten sam niedostatek zaciążył na decyzji rodziców małego Wojciecha.

Fundamentalną opozycję między ziemią a niebem hagiograf dyskontuje również w opowieści o edukacji bohatera. Płoche harce kolegów i ich słabość do wykradanych nauczycielowi słodyczy czyni tu tłem dla ukazania Wojciechowego zaangażowania w sprawy ducha. Odmienność postaw akcentuje z pomocą ulubionej retorycznej figury: czcze igraszki młodzieży zderza z przypisanym świętemu ,spiritali risu”, podkradaniu smakołyków przeciwstawia jego "furtiuas orationes" 32 . I tym razem oksymoroniczny charakter sformułowań najlepiej oddaje ich literalny przekład: „śmiech duchowy" i ,wykradane modlitwy" ${ }^{3}$.

${ }^{27}$ A. Weiss, op. cit., s. 38.

${ }^{28}$ Połączenie to jest właściwe monastycznemu rozumieniu prawdziwej „filozofii”, por. zwł. J. Leclercq, Miłość nauki a pragnienie Boga, Tyniec-Kraków 1997 (oryg. franc. 1957), s. 125 n.

${ }^{29}$ Por. M. P.J. van den Hout, A Commentary on the Letters of M. Cornelius Fronto, Leiden-Boston-Köln 1999, s. 64 [ad 25,5].

${ }^{30}$ Udało się znaleźć jedną tylko, znaczeniem i kontekstem odległą analogię, por. [Pseudo-]Primasii Adrumetani episcopi Commentaria in epistolas s. Pauli, PL, t. 68, kol. 571A (tekst przypisywany nieznanemu z imienia uczniowi Kasjodora, Clavis patrum latinorum, wyd. 3, oprac. E. Dekkers, E. Gaar, Steenbrugis 1995, CCh SL, nr 902, s. 296).

31 ,ut [--] pium parentis errorem intellegeres, cui, ut amorem in te tribuam, amoris scientiam non concedo", S. Eusebii Hieronymi Epistulae, cz. 1, nr 54, c. 6, 1, s. 471 (przywołując dalej Rz 10,2). Por. też „pius licet, attamen coarguendus error”, ibidem, nr 18B, c. 1 (17), 4, s. 98; ,pio labuntur errore”, idem, Commentariorum in Esaiam libri I-XVIII, wyd. M. Adriaen, Turnholti 1963, CCh SL, t. 73-73A, lib. 10, 34, 1/7, s. 420; „pio errore lapsi", ibidem, lib. 17, 63, 1, s. 721.

${ }^{32}$ VA I/A, c. 4, s. 8. Tak też J. Hoffmann, VA, s. 34 (Aq, f. 104ra).

${ }^{33}$ Por. „radość ducha”, „tajemne modły”, ŻW I (K.A.), s. 32 = ŻW I (B. K.), s. 45; „,in geistlichem Lächeln”, „heimliche Gebete”, Das Leben des Bischofs Adalbert von Prag, tłum. H. Hüffer, wyd. 2, Leipzig 1891, s. 7 (podobnie: J. Hoffmann, VA, s. 162); „duchovní 
Ponieważ rzeczownik risus miewał niekiedy znaczenie zbliżone do polskiej radości ${ }^{34}$, taką interpretację pierwszego wyrażenia wolno by może kwestionować. Przesądza o niej jednak kontekst wzmianki (risus Wojciecha to nawiązanie do świata jego rówieśników oddających się „inanibus ludis et ioco") oraz fakt, że autor - gdyby nie zależało mu na paradoksie miał do dyspozycji inne, neutralne czy przynajmniej łagodniejsze określenia, np. gaudium lub laetitia. Trudno mniemać, że przez przypadek tylko wybrał słowo o tak negatywnych - zwłaszcza w środowiskach monastycznych - konotacjach ${ }^{35}$. Musiał być świadom, że zastosowany dla opisu praktyk pobożnych risus u wielu odbiorców - a już na pewno wśród obeznanych z Reguła św. Benedykta mnichów - wywoła szczere zdumienie ${ }^{36}$. Najwyraźniej taki właśnie efekt chciał osiągnąć. Warto odnotować, że rękopisy redakcji $B_{1}$ Żywota mają w tym miejscu inną lekcję. Nie wspominają o „duchowym śmiechu”, lecz żywią Wojciecha „duchowym pokarmem” („spirituali esu”) ${ }^{37}$. Najprościej wyjaśnić taką zmianę paleograficzną

zábavou”, „tajné modlitby”, Canapariova vojtěšská legenda Est locus, tłum. J. Zachová, w: Slavníkovci ve středověkém písemnictví, red. R. Nový, J. Sláma, J. Zachová, Praha 1987, s. 124-125; „spiritual merriment”, „stealthy prayers”, C. Gaşpar, VA, s. 105 (z komentarzem, ibidem, s. 104, przyp. 4).

${ }^{34}$ Np. Piotr Damiani pisał o szczęściu zbawionych: „exiguae lacrimae risum pariunt sempiternum”, Die Briefe des Petrus Damiani, wyd. K. Reindel, cz. 1-4, München 1983-1993, MGH Die Briefe der deutschen Kaiserzeit, t. 4, cz. 1, nr 28, s. 273. Por. „risus cordis", VA I/A, c. 28, s. 42 (zapożyczenie z Grzegorza Wielkiego, C. Gaşpar, VA, s. 171, przyp. 4), „radość serca”, ŻW I (K. A.), s. 80 = ŻW I (B. K.), s. 73. Z drugiej strony, por. „lęticię risu exuberat”, VA I/A, c. 26, s. 39, „radosnym wybuchnął śmiechem”, ŻW I (K. A.), s. 75; ŻW I (B.K.), s. 71 (podobnie).

35 O stosunku wczesnośredniowiecznych mnichów do śmiechu zob.np. B. Steidle, Das Lachen im alten Mönchtum, „Benediktinische Monatsschrift” 20, 1938, s. 271-280; G. Schmitz, ...quod rident homines, plorandum est. Der „Unwert” des Lachens in monastisch geprägten Vorstellungen der Spätantike und des frühen Mittelalters, w: Stadtverfassung, Verfassungsstaat, Pressepolitik. Festschrift für Eberhard Naujoks zum 65. Geburtstag, red. F. Quarthal, W. Setzler, Sigmaringen 1980, s. 3-15; J. Le Goff, Le rire dans les règles monastiques du Haut Moyen Âge, w: Haut Moyen Âge. Culture,éducation et société. Études offertes à Pierre Riché, red. M. Sot, Nanterre 1990, s. 93-103, i przyp. następny.

${ }^{36}$ Por. La Règle de saint Benoît, wyd. A. de Vogüé, J. Neufville, t. 1-2, Paris 1972, Sources Chrétiennes, t.181-182, zwł. c. 6, 8, s. 472, c. 7, 59-60, s. 486-488. O stosunku do śmiechu w Regule zob. zwł. P. M. Alexander, La prohibición de la risa en la Regula Benedicti: intento de explicación e interpretación, „Regulae Benedicti Studia” 5, 1976, s. 225-283. Kimkolwiek był autor Vita prior, jego znajomość Reguły św. Benedykta pozostaje poza sporem.

${ }^{37}$ VA I/B, c. 4, s. 53. Odnaleziony w Cape Town rkp. z rzymskiego klasztoru św. Cecylii (spisany w XI w. reprezentant redakcji $\mathrm{B}_{2}$ ) ma zepsutą lekcję: „,spiritali refuse solatur", National Library of South Africa, Cape Town, Grey Collection, 48.b.4 (dalej: Cc), f. 88r (piszący te słowa korzystał z fotokopii manuskryptu uzyskanej z Hill Museum \& Manuscript Library, Saint John's University, Collegeville, Minnesota, i wdzięczny jest za pomoc okazaną mu w tym względzie przez p. Julie Dietman). Por. „spirituali gaudio”, VA I/C, c. 4, s. 72. Czy do wprowadzenia poprawki zmusiło redaktora C uszkodzenie 
pomyłką, ale w tej sytuacji nie da się chyba wykluczyć świadomej poprawki banalizującej pierwotny, zbyt szokujący tekst. Pod względem konstrukcyjnym oksymoron nie jest wprawdzie wierną kopią „miłosnego błędu” czy „złej życzliwości”, ale i on wyrasta z połączenia pojęć reprezentujących odmienne porządki: śmiech pochodzi z grzesznego świata niesfornych młodzieńców, przymiotnik spiritalis odnosi się explicite do sfery ducha. Wojciech „śmiał się” więc jak koledzy, ale naprawdę całkiem inaczej: „risus spiritalis" stanowił zaprzeczenie ich płochych igraszek.

„Furtiuae orationes” to przypadek podobny. Jeśli bledszy w wyrazie, to dlatego, że wyrażenie należało do stosunkowo popularnych. Użył go niegdyś Grzegorz Wielki ${ }^{38}$, a późniejsi pisarze skwapliwie powtarzali ${ }^{39}$. Chodziło - rzecz jasna - o modlitwy zanoszone potajemnie, w ukry$\mathrm{ciu}^{40}$. Tę wspólną wielu świętym praktykę hagiograf przywołał przecież w szczególnych okolicznościach: uczynił z niej paralelę dla występków Wojciechowych rówieśników, tj. podkradania słodyczy. „Kradzież” modlitw służąca (co zaznacza wprost) uzyskaniu wiecznej strawy jako antyteza służącej jedynie chwilowej przyjemności kradzieży smakołyków oto jego retoryczny zamysł w pełnej krasie ${ }^{41}$. Umieszczone w takim kon-

podstawy? Tak zdawała się mniemać J. Karwasińska, Studia krytyczne na żywotami św. Wojciecha, biskupa praskiego, III: Redakcje Vita I, St. Źr. 4, 1959, s. 9-32, tu s. 29. Sama jednak konkludowała, że na Monte Cassino wykorzystano nieznany rkp. redakcji $\mathrm{B}_{2}$ różny od Cc, VA I, wstęp, s. XXIX.

${ }^{38}$ Gregorius Magnus, Homiliae in Evangelia, wyd. R. Étaix, Turnhout 1999, CCh SL, t. 141, lib. 2, hom. 34, 18, s. 317. Ten pierwowzór sformułowania wskazał C. Gaşpar, VA, s. 104, przyp. 4. Por. też „furtivis vicibus orare non cessabat”, Passio s. Susannae [BHL 7937, VI w.?], wyd. G. Cuypers, w: Acta Sanctorum, Augusti t. 2, Antverpiae 1735, c. 6, s. 632.

${ }^{39}$ Zob. m.in. H. Quentin, Les martyrologes historiques du Moyen Âge. Étude sur la formation du martyrologe romain, Paris 1908, s. 181 (martyrologium z Lyonu, IX w., natale s. Matronae, 15 III); Le martyrologe d'Adon. Ses deux familles, ses trois recensions. Texte et commentaire, wyd. J. Dubois, G. Renaud, Paris 1984, s. 106 (natale s. Matronae, 15 III), 268 (natale s. Susannae, 11 VIII); Vita s. Iuniani abbatis Mariacensis auctore Vulfino Boetio [BHL 4562, IX w.], wyd. L. d'Achéry, J. Mabillon, w: Acta Sanctorum ordinis Sancti Benedicti, t. 1, Lutetiae Parisiorum 1668, c. 4, s. 309; Adventius Mettensis episcopus, Epistola Nicolao papae [864 r.], wyd. E. Dümmler, w: Epistolae ad divortium Lotharii II regis pertinentes, MGH Epistolae, t. 6, Berolini 1925, nr 8, s. 222; Ruotgeri Vita Brunonis archiepiscopi Coloniensis [BHL 1468], wyd. I. Ott, Wimariae 1951, MGH SrG n.s., t. 10, c. 30, s. 30. Por. „consueta orationis furta", Historia translationis s. Benedicti auctore Adrevaldo [BHL 1117, IX w.], wyd. E. de Certain, w: Les miracles de saint Benoît écrits par Adrevald, Aimoin, André, Raoul Tortaire et Hugues de Sainte Marie moines de Fleury, Paris 1858, c. 15, s. 13. Zob. też przyp. następny.

${ }_{40}$ Zob. np. Vita Faronis episcopi Meldensis [BHL 2825, IX w.], wyd. B. Krusch, MGH Scriptores rerum Merovingicarum (dalej: SrM), t. 5, Hannoverae-Lipsiae 1910, c. 119, s. 199; Vita Walarici abbatis Leuconaensis [BHL 8762, XI w.], wyd. B. Krusch, MGH SrM, t. 4, Hannoverae-Lipsiae 1902, c. 30, s. 172.

${ }^{41}$ Podobnie C. Gaşpar, VA, s. 104, przyp. 4. 
tekście również „furtiuae orationes” łączą więc w zaskakującą całość dwa obce sobie światy: rozbrykaną codzienność szkolnych urwisów (wykradanie) ze zwiastującą świętość, wytrwałą pobożnością (modły). W porównaniu $\mathrm{z}$ „duchowym śmiechem” ten paradoks - z racji popularności sformułowania - był jednak słabszy w wymowie i współczesnych nie mógł raczej razić. Nic dziwnego, że późniejsze redakcje powtórzyły go bez zmian ${ }^{42}$.

Chwilę dalej w tekście pojawia się nowy oksymoron wyrosły ze zderzenia porządków. Mowa o tytułowej „dobrej głupocie” - wtrąconym do wywodu wykrzyknieniu, stanowiącym odautorski komentarz do historii słynnego sztubackiego żartu: przewrócony przez jednego z kolegów na przypadkową dziewczynę, Wojciech uznaje jej dotknięcie za równoznaczne $\mathrm{z}$ aktem seksualnym ${ }^{43}$. „Bona stultitia” doskonale pasuje do opisanego modelu: to, co ogół śmiertelników poczytałby za świadectwo śmiechu wartej ignorancji, z wiecznej perspektywy trzeba ocenić wysoko. Ten akurat paradoks zasługuje jednak na specjalną uwagę i nie przypadkiem znalazł się w tytule artykułu: zdaje się wręcz kluczem do interpretacji niektórych innych „niezwykłości”, jakimi hagiograf okrasił swój tekst.

Wiele do myślenia daje na początek szerszy kontekst oksymoronu. Historyjka z dziewczyną stanowi integralną część opowieści o edukacji Wojciecha. Trudno tu widzieć jedynie zbieg okoliczności: dosadna ilustracja prostoduszności bohatera tworzy zastanawiające pendant dla zawartej w finale rozdziału pochwały jego doczesnej uczoności. Tak, jakby hagiograf szukał dla tej ostatniej - spektakularnej przeciwwagi. Okazuje się bowiem, że ziemskich nauk twórca Żywota raczej nie cenił (o wszystkim będzie jeszcze mowa). Dobór słów potwierdza te podejrzenia. W pierwszym zdaniu historii autor deklaruje zamiar ukazania Wojciechowej „świętej prostoduszności” (,sanctę simplicitatis”) ${ }^{44}$. Stosownie do tego, w toku

${ }^{42}$ VA I/B, c. 4, s. 53; VA I/C, c. 4, s. 72.

${ }^{43}$ „Ille uero, quia uestitam uirginem tetigit, o bona stultitia! iam se nupsisse uerissime credidit", VA I/A, c. 5, s. 8. Tak też J. Hoffmann, VA, s. 35 (Aq, f. 104ra). Nubere oddawano polskim „ożenić się”, „poślubić”, ŻW I (K. A.), s. 33; ŻW I (B. K.), s. 45; por. też np. J. Hoffmann, VA, s. 162. Słusznie jednak C. Gaşpar ((Re)claiming, s. 32; idem, VA, s. 106, przyp. 1) akcentuje seksualny podtekst sceny i argumentuje na rzecz dosadniejszego przekładu („I had sex!”, ibidem, s. 107). Obie interpretacje nie wykluczają się, zob. A. Krawiec, Seksualność w średniowiecznej Polsce, Poznań 2000, s. 65 n. G. Labuda (Święty Wojciech, s. 100) i M. Sosnowski (op. cit., s. 146, przyp. 281) kojarzą scenkę z obrzędem pokładzin. W. Berschin (op.cit., s. 163, przyp. 487) sygnalizuje erotyczne konotacje użytego w takim kontekście tangere.

${ }^{44}$ „Videamus nunc inter alias uirtutes, quas habuit, sanctę simplicitatis quam ditissimus erat", VA I/A, c. 5, s. 8. Miejsce to istotnie różni się w rękopisach Ll, Aq i Rv 2 . Wspominają one „świętą prostoduszność”, ale dodają, że historyjka ukazuje zarazem czystość (castitas) świętego, VA I/A, c. 5, s. 8, przyp. c-f (z uwzględnieniem erraty); 
wywodu nazywa go „chłopcem dobrej prostoty” („bene simplex puer”) Pojawiająca się pomiędzy jednym a drugim sformułowaniem „bona stultitia", jakkolwiek bliskoznaczna, nie jest do końca tożsama znaczeniowo. Stultitia, mimo niezaprzeczalnego semantycznego pokrewieństwa, nie stanowiła prostego synonimu simplicitas ${ }^{46}$. Nie chodzi tylko o silniejsze zabarwienie pejoratywne, które pozwoliło zbudować oksymoron. Różnice w konotacjach obu pojęć sięgały dalej. Wystarczy zauważyć, że paradoksalna apologia „głupoty” wydaje się dużo czytelniejszym niż pochwała „prostoduszności” wyzwaniem rzuconym wielbicielom „ziemskiej filozofii”, o której mowa w zakończeniu rozdziału.

Mimo że nazwanie bohatera „dobrym głupcem” służyło w istocie uczczeniu go i powinno sprowokować nobilitujące skojarzenia („nos stulti propter Christum" - pisał św. Paweł o apostołach) ${ }^{47}$, stanowiło jednak akt odwagi. Wiązało się bowiem z ryzykiem zgorszenia mniej wyrobionej publiczności, „maluczkich”. Późniejsze losy tekstu dowodzą, że niektórzy czytelnicy faktycznie uznali oksymoron za niestosowny ${ }^{48}$. Twórca redak-

J. Hoffmann, Vita Adalberti Aquensis, „Deutsches Archiv für Erforschung des Mittelalters" 57, 2001, s. 157-163, tu s. 161 n. i przyp. 35; idem, VA, s. 35 (Aq, f. 104ra), 66 n. Dopisek ten J. Fried (op. cit., s. 243 n., przyp. 36) i J. Hoffmann (idem, VA, s. 66 n., 95 n., 130; idem, Der Adalbertskult, s. 611) uznali za oryginalny. Ich pogląd podzielił też C. Gaşpar ((Re)claiming, s. 34 n.; idem, VA, s. 104 n. i przyp. 5). Słusznie jednak M. Sosnowski (op. cit., s. 46 n., por. wszakże: s. 146, przyp. 282) poddał tezę niemieckich badaczy krytyce, argumentując, że bez dodatku opowiastka jest znacznie bardziej spójna: hagiograf konsekwentnie akcentuje dalej właśnie „prostoduszność” (vel „dobrą głupotę”) bohatera, o „czystości” nie wspomina. Wzmiankę o castitas należy w tej sytuacji uznać za interpolację sprowokowaną pewnie seksualnymi konotacjami historii. Zob. niżej przyp. 138.

${ }^{45}$ VA I/A, c. 5, s. 8. Tak też J. Hoffmann, VA, s. 35 (Aq, f. 104ra).

${ }^{46}$ Por. „simplicitas absque ratione, stultitia nominatur”, S. Hieronymi Commentariorum in Osee prophetam libri III ad Pammachium, wyd. M. Adriaen, w: S. Hieronymi presbyteri Commentarii in prophetas minores, Turnholti 1969, CCh SL, t. 76, lib. 2, c. 7, 11.12, s. 77; „ignorantia quoque ipsa atque stultitia simplicitatis et innocentiae nomine tegitur", S. Augustini Confessionum libri XIII, wyd. L. Verheijen, Turnholti 1981, CCh SL, t. 27, lib. 2, c. 6, 13, s. 24; „Inordinate dici seu conferri uitiis ea quae ordinate in Deo sunt, utpote simplicitas, quae aliquando dicitur pro stultitia, et non est", Isidorus Hispalensis, Sententiae, wyd. P. Cazier, Turnholti 1998, CCh SL, t. 111, lib. 1, c. 1, 6b, s. 8.

${ }^{47} 1$ Kor 4,10, por. 1 Kor 3,18 n.; M. Sosnowski, op. cit., s. 146. Dziwnie znajomo brzmi w tym kontekście nagłówek ostatniego ustępu (łacińskiej wersji) Reguły św. Bazylego: „Quomodo fit aliquis in praesenti saeculo stultus?”, Basili Regula a Rufino Latine versa, wyd. K. Zelzer, Vindobonae 1986, CSEL, t. 86, c. 203, s. 220 (wydawca widzi nawiązanie do 1 Kor 3,18 ). Nie wiadomo, czy hagiograf ją znał. Wspomniał o niej przy innej okazji (VA I/A, c. 15, s. 22), ale uczynił to w słowach zaczerpniętych z Reguły św. Benedykta, VA I/A, s. 22, przyp. 81; H. G. Voigt, op. cit., s. 14 n.

${ }^{48}$ Nawet dziś bywa czasem łagodzony przez tłumaczy, por. „o święta naiwność”, ŻW I (K.A.), s. 33; „o prostoduszna naiwności”, ŻW I (B. K.), s. 45. 
cji $\mathrm{B}_{1}$, działając najwyraźniej z rozmysłem, zastąpił go banalnym „ob hanc causam” ${ }^{49}$. Również w wersji C „dobrej głupoty” próżno szukać ${ }^{50}$. Czyżby autor Vita prior odznaczał się inną wrażliwością i nie widział problemu? A może - z zarysowanych właśnie powodów - aż tak zależało mu na niecodziennej konstatacji, że ośmielił się podjąć ryzyko?

Kolejny rozdział Żywota przynosi nowe paradoksy omawianego typu. Za sprawą hagiografa czytelnicy mają okazję - pospołu z Wojciechem zatrwożyć się treścią ostatniej przemowy umierającego biskupa praskiego. Dostojnik poniewczasie konstatuje nędzę materialnego świata. Doczesne bogactwa wydają mu się teraz bezwartościowe (,inanes diuicię”), z gorzką ironią wspomina o „chwale i pięknie marności” („gloria et pulchritudo uanitatis") ludzkiego ciała ${ }^{51}$. Oba oksymorony wyrastają z tego samego aksjologicznego konfliktu: cenione przez ludzi bogactwa i cielesne piękno $z$ wiecznej perspektywy tracą znaczenie. W swoich stylistycznych poszukiwaniach hagiograf nie oddalił się zanadto od utartych szlaków. Pierwsze z wyrażeń - zainspirowane może wersetem Magnificat (Łk 1,53) - posiada dość bliskie analogie w innych utworach ${ }^{52}$, drugie - nieco bardziej oryginalne - przypomina określenie „gloria uanitatis” znane zwłaszcza z pism św. Augustyna i Jana Kasjana ${ }^{53}$.

„Duchowy śmiech" i „wykradane modlitwy” mają w tekście bez mała brata bliźniaka. Opisując nocne modły, którym Wojciech oddawał się jako biskup, hagiograf sięgnął po osobliwą metaforę: „solite orationis

${ }^{49}$ VA I/B, c. 5, s. 53. Por. „o bona stultas”, Cc, f. 88 r.

50 „ob impulsum stulti”, VA I/C, c. 5, s. 73. Wedle J. Karwasińskiej (zob. prace cyt. w przyp. 37) redaktor $C$ korzystał z nieznanego rękopisu redakcji $\mathrm{B}_{2}$, według J. Frieda (op. cit., s. 242, przyp. 30, s. 247, 249 n., 253, 262), z nieznanego rękopisu redakcji B, bliskiego A. Tak czy inaczej, nie ma pewności, jaką lekcję widział w podstawie. Najwyraźniej było tam jednak słowo o temacie „stult-” (skoro sam takiego użył). Bardzo możliwe, że ów zaginiony rkp. miał więc lekcję „bona stultitia” lub odmiankę właściwą Cc (zob. przyp. poprzedni), która pozwalała odgadnąć zamierzony przez autora sens. Jeśli tak, również poprawkę redaktora $C$ trzeba rozumieć jako wyraz dezaprobaty dla szokującego wyrażenia.

51 ŻW I (K. A.), s. 35; VA I/A, c. 6, s. 10. Por. J. Hoffmann, VA, s. 35 (Aq, f. 104va); VA I/B, c. 6, s. 54; VA I/C, c. 6, s. 73 - wszędzie oba wyrażenia bez zmian.

52 Por. np. „Divitias animo fortis calcavit inanes”, Vulfinus, Carmen de Marcello episcopo Diensi [BHL 5247b, VIII/IX w.], wyd. K. Strecker, MGH Poetae Latini, t. 4, cz. 3, Berolini 1923, s. 965, 1. 21; „divitiae [--] quia transitoriae erant et inanes”, Conversio Othgerii militis [BHL 2831, XI w.], wyd. B. Krusch, MGH SrM, t. 5, c. 2, s. 204.

53 Sancti Aurelii Augustini De civitate Dei, libri 1-10, Turnholti 1955, CCh SL, t. 47, lib. 6, praef., s. 164; Iohannes Cassianus, Collationes XXIIII, wyd. M. Petschenig, G. Kreuz, wyd. 2, Wien 2004, CSEL, t. 13 (dalej: Jan Kasjan, Collationes), Conlatio 6, c. 10, 4, s. 164; idem, De institutis coenobiorum et de octo principalium uitiorum remediis libri XII, wyd. M. Petschenig, G. Kreuz, wyd. 2, Wien 2004, CSEL, t. 17, lib. 11, c. 10, 1, s. 199 („uanitatis gloriatione"); c. 13, s. 201. Por. też ibidem, lib. 11, c. 4, s. 196. 
conuiuia"54. Sformułowanie stało się ostatnio przedmiotem sporu. Rękopis z Akwizgranu ma w tym miejscu lekcję: „solite orationis communia" ${ }^{55}$. Johannes Fried i Jürgen Hoffmann skłaniają się ku uznaniu jej za lepszą ${ }^{56}$. Słusznie jednak Miłosz Sosnowski - przywołując m.in. zasadę lectio difficilior - podał ich opinię w wątpliwośćc ${ }^{57}$. W „ucztach zwyczajnej [mu, tj. Wojciechowi] modlitwy" rozpoznać należy kolejny przejaw stylistycznych upodobań hagiografa. Ponieważ metaforyka „strawy duchowej" była raczej popularna ${ }^{58}$, oksymoron nie wydaje się rażący, ale i on zdradza ślad owego semantycznego napięcia wynikłego z konfrontacji sprzecznych systemów wartości. Wyrażenie trzeba odczytywać w kontekście całego zdania, które rozpoczyna się od stwierdzenia, że święty nigdy nie szedł spać syty. Modlitwy były jego ucztą - poucza autor, ponownie zderzając w jednym określeniu święte z nieświętym: Wojciechową pobożność z obyczajami rozmiłowanych w jak najprzyziemniej pojętych, sutych biesiadach - zwykłych śmiertelników. Lekcja akwizgrańskiego pasjonału wynikła najpewniej z paleograficznej pomyłki ${ }^{59}$. W przeciwnym razie dowodziłaby, że i ten pomysł hagiografa wzbudził opór.

Jednym z powodów, dla których Wojciech porzucił biskupstwo, miała być sprzedaż chrześcijańskich niewolników Żydom. Kruszcowi pochodzącemu z tych transakcji autor przypisał swego rodzaju skazę, mieniąc

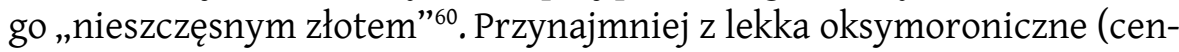

${ }^{54}$ „Numquam saturo uentre iuit dormitum, et nondum expleto sopore, surgit ad solite orationis conuiuia", VA I/A, c. 9, s. 14 n. Bez istotnych różnic: VA I/B, c. 9, s. 55; VA I/C, c. 9, s. 75.

${ }^{55}$ J. Hoffmann, VA, s. 37 (Aq, f. 105vb). Por. J. Fried, op. cit., s. 244 n., przyp. 38. Onegdaj J. Hoffmann, Vita Adalberti Aquensis, s. 161, cytował lekcję Aq nieco inaczej: „com[m]unia".

${ }^{56}$ J. Fried, op. cit., s. 244 n., przyp. 38 (wskazując, że „orationis conuiuia” są skądinąd nieznane i nie przystają do treści opowiadania; z konkluzją w trybie przypuszczającym); J. Hoffmann, VA, s. 55 („die wohl authentische Formulierung”), s.134.

${ }^{57}$ M. Sosnowski, op. cit., s. 45 n. Wyższość lekcji „communia” odrzucił wcześniej G. Labuda (W sprawie, s. 128, przyp. 61).C. Gaşpar (idem, VA, s. 118) zachował w tekście „conuiuia”.

${ }^{58}$ Nie stronił od niej sam hagiograf, „sacre lectionis cibaria”, VA I/A, c. 10, s. 16; „esca et potus erat laus perpetua Creatoris”, ibidem, c. 20, s. 31, por. A. Kozłowska, Leksyk dotyczacy Boga w żywotach św. Wojciecha, „Studia Warmińskie” 27, 1990, s. 157-165, tu s. 159. Por. też M. Sosnowski, op. cit., s. 45 n.

${ }^{59}$ Rozważa ją M. Sosnowski, op. cit., s. 45.

60 ŻW I (K.A.), s. 45 = ŻW I (B.K.), s. 53; „quos mercator Iudeus infelici auro emerat", VA I/A, c. 12, s. 18. Aq ma inny szyk wyrazów, J. Hoffmann, VA, s. 38 (Aq, f. 106vb). Por. VA I/B, c. 12, s. 57; VA I/C, c. 12, s. 76 (wyrażenie bez zmian). o precyzyjniejszy przekład pokusił się Maurice Lombard, Les bases monétaires d'une suprématie économique. L'or musulman du VIIe au XIe siècle, „Annales. Économies, Sociétés, Civilisations” 2, 1947, s. 143-160, tu s. 155: „l'or qui porte le malheur avec lui”. 
ny metal kojarzy się na ogół jak najszczęśliwiej), wyrażenie wydaje się pokrewne omawianej grupie paradoksów. Sens nieszczęścia staje się jasny za sprawą opisanej dalej wizji świętego. Gość, który nawiedza go we śnie, przedstawia się jako: „Jezus Chrystus, którego sprzedano; i oto znowu sprzedają mnie Żydom" "61. Wynika stąd, że złoto oferowane za chrześcijańskich niewolników stanowi odpowiednik Judaszowych srebrników, jest nieszczęsne, bo jako narzędzie i owoc grzechu przynosi moralną zgu$\mathrm{bę}^{62}$. Również „infelix aurum” wyrasta więc z konfrontacji dwóch porządków: wrażliwej na duchowe szkody etyki i żądnej materialnych zysków ekonomii.

Opuściwszy Pragę, Wojciech udał się do Rzymu, by po rozmowie z papieżem zdecydować o trwałym rozstaniu z ojczyzną. Objaśniając w tym miejscu bliskie bohaterowi ideały, autor ponownie przypomina o fundamentalnym konflikcie postaw i wartości. Posługuje się w tym celu antytetycznymi zestawieniami o paradoksalnym wydźwięku: „Wszystko, co twarde i przykre, ze względu na umiłowanie Jezusa wydawało mu się [tj. Wojciechowi] słodkie; dla bogatego Chrystusa znosić dotkliwe ubóstwo to był nie tyle trud, jak raczej dowód ogromnej miłości" ${ }^{33}$. Pary przeciwieństw: „,dura et aspera”/,dulcia” oraz „labor”/ ,amor” również realizują schemat zderzenia porządków (pierwszy człon odpowiada w obu wypadkach wyobrażeniom pospolitych śmiertelników). Rozdzielający je paradoks o nieco bardziej wyrafinowanej konstrukcji („pro diuite Christo angustam pauperiem pati") powstał na drodze zręcznej kombinacji cytatów. Dostrzeżono tu adaptację horacjańskiego zwrotu ,angustam amice pauperiem pati" ${ }^{4}$, ale dodać trzeba także werset anonimowego, późnoantycznego poety: „pauperiem Christo diuite non metuam” ${ }^{65}$. Przesłanie, które hagiograf tak zgrabnie odział w cudze słowa, odwołuje się do tej samej

${ }^{61} \dot{Z} W \mathrm{I}$ (K. A.), s. 45; VA I/A, c. 12, s. 18.

${ }^{62}$ Por. Mt 27,6; Dz 1,18. Por. K. Potkański, Święty Wojciech, w: idem, Pisma pośmiertne, oprac. F. Bujak, Poznań 2004 (wyd. 1: Kraków 1922-1924), s. 522-531, tu s. 523.

${ }^{63}$ ŻW I (K. A.), s. 47; VA I/A, c. 13, s. 19 (z nawiązaniem do Reguły św. Benedykta, ibidem, przyp. 70). Tak też (pomijając ortografię): J. Hoffmann, VA, s. 39 (Aq, f. 107rb); VA I/B, c. 13, s. 57. Por. VA I/C, c. 13, s. 77 (niewielkie różnice). Por. H.G. Voigt, op. cit., s. 27; C. Gaşpar, VA, s. 128, przyp. 10.

${ }^{64}$ Horace, Carmina, w: idem, Odes et Épodes, wyd. F. Villeneuve, J. Hellegouarc'h, Paris 1991, lib. 3, nr 2, 1.1, s. 97; M. Manitius, op. cit., s. 230, przyp. 2; W. Berschin, op. cit., s. 164.

${ }^{65}$ Carmen [coniugis ad uxorem], wyd. G. de Hartel, M. Kamptner, w: Sancti Pontii Meropii Paulini Nolani Carmina, wyd. 2, Vindobonae 1999, CSEL, t. 30, Appendix, nr 1, 1. 110, s. 347; H. Walther, Proverbia sententiaeque Latinitatis Medii Aevi. Lateinische Sprichwörter und Sentenzen des Mittelalters in alphabetischer Anordnung, cz. 3, Göttingen 1965, s. 325 , nr 18051. W sprawie atrybucji tekstu zob. A. Y. Hwang, Intrepid Lover of Perfect Grace: The Life and Thought of Prosper of Aquitaine, Washington 2009, s. 26 n. 0 „,bogatym” Chrystusie pisał św. Paweł (2 Kor 8,9), C. Gaşpar, VA, s. 128, przyp. 9. 
aksjologicznej opozycji: drogą wiodącą do (duchowych) bogactw w niebie okazuje się tak niemiłe grzesznemu ogółowi materialne ubóstwo ${ }^{66}$.

Na cesarskim dworze Wojciech dał dowód niezwykłej pokory, nocami potajemnie czyszcząc wszystkim obuwie. Pewnego razu przyłapano go na tym, co autor opisuje w sposób dla siebie typowy, informując o „ujawnieniu świętego złodzieja” ${ }^{67}$. „Sanctus fur” to kolejny oksymoron wynikły z przemieszania porządków („święty” - wedle prawdziwej, niebieskiej miary, ,złodziej” - jeśli zwyczajem ludzi sądzić po pozorach). Sam w sobie nie grzeszy może oryginalnością - kojarzy się z ideą „świętej kradzieży"68 - ale w takim kontekście pozostaje chyba własnym pomysłem hagiografa. Pod pewnym względem przypomina „dobrą głupotę”: raz jeszcze dla spotęgowania kontrastu do Wojciecha odniesiono określenie o niepokojąco silnym zabarwieniu pejoratywnym ${ }^{69}$. Czytelnik z innej epoki zganiłby pewnie retoryczną przesadę: przypisanie postępowaniu świętego znamion kradzieży wydaje się mocno na wyrost. Współcześni odczuwali to jednak inaczej. Etymologia słowa furtum sprawiała, że działanie potajemne, w mrokach nocy tak właśnie się kojarzyło ${ }^{70}$. Paradoks nie wydawał się więc oderwany od rzeczywistości. Pozostałe redakcje Żywota mają lekcję nieco chyba łagodniejszą w wymowie, ale także paradoksalną: piszą o „szlachetnym złodzieju”71. Być może, powstała ona w związku ze zmianami, jakie redaktor B wprowadził do charakterystyki sługi cesarskiego, który przyłapał Wojciecha ${ }^{72}$.

${ }^{66}$ Por. M. van Uytfanghe, Stylisation, s. 133 n.

${ }^{67}$ „quidam Uolpharius, imperialis minister et sibi dilectus cubicularius, sanctum prodidit furem", VA I/A, c. 23, s. 36. Bez istotnych różnic: J. Hoffmann, VA, s. 46 (Aq, f. $111 \mathrm{vb}), 57$.

${ }^{68}$ Zob. P. Geary, Furta Sacra: Thefts of Relics in the Central Middle Ages, wyd. 2, Princeton 1990. Proste oksymorony oparte na tym pomyśle nie były chyba we wcześniejszym średniowieczu aż tak popularne, zob. np., ,sancta rapina”, Vita s. Eligii episcopi Noviomagensis [BHL 2474], wyd. B. Krusch, MGH SrM, t. 4, lib. 2, c. 37, s. 721. W innym kontekście por. np. „pio furto paternae benedictionis”, S. Ambrosii Expositio psalmi CXVIII, wyd. M. Petschenig, M. Zelzer, wyd. 2, Vindobonae 1999, CSEL, t. 62, 20 (Littera Res), c. 6, s. 448.

${ }^{69}$ Jako pozornego złodzieja biograf ukazał Wojciecha już wcześniej, opowiadając, jak święty potajemnie obdarował potrzebującego jedwabną powłoczką. Nazwał zdarzenie „kradzieżą", jakby opisywał je z punktu widzenia nieświadomego prawdy komornika Myśla, VA I/A, c. 11, s. 16; W. Berschin, op. cit., s. 164.

${ }^{70}$ Zob. P. Geary, op. cit., s. 109. Uczony cytuje Izydora z Sewilli: „Furtum est rei alienae clandestina contrectatio, a furvo, id est fusco vocatum, quia in obscuro fit", Isidori Hispalensis episcopi Etymologiarum sive originum libri XX, wyd. M. Lindsay, t. 1, Oxonii 1911, lib. 5, 26, 18.

${ }^{71}$ VA I/B, c. 23, s. 63; VA I/C, c. 23, s. 81.

${ }^{72}$ Nazwał Wolfariusa „szlachetnym”, VA I/B, c. 23, s. 63. Repetycja nobilis - nobilem mogła się wydać kusząca. 
Na marginesie listy paradoksów opartych na omawianym schemacie wspomnieć trzeba wreszcie wyrażenie „felici lapsu”, które pojawia się w redakcjach B i C Żywota w opisie męczeńskiej śmierci świętego ${ }^{73}$. Oksymoron wiernie realizujący opisane założenia (kojarzony pospolicie z porażką upadek umierającego z wiecznej perspektywy okazuje się drogą do prawdziwego szczęścia) zastąpił znane z redakcji cesarskiej słowa „protenta cruce”74. Ten stan rzeczy musi zastanawiać. „Szczęśliwy upadek” doskonale odpowiada stylistycznym upodobaniom hagiografa. Z drugiej strony lekcja redakcji A wydaje się trudniejsza ${ }^{75}$, co więcej - pasuje do forsowanej przez autora analogii Wojciech-Chrystus ${ }^{76} \mathrm{i}$ związanego $\mathrm{z}$ nią, nieobecnego $\mathrm{w}$ redakcjach B i C komentarza ${ }^{77}$. Wynikałoby stąd, że oksymoron pochodzi jednak od redaktora B, który udanie „podrobił” styl poprzednika ${ }^{78}$. Problem wymagałby dalszych badań.

Omówione dotąd paradoksy zbudowane na zasadzie konfliktu porządków mają zgodnie z intencją autora łatwe rozwiązanie o jasnym, dydaktycznym przesłaniu. W prostych (dwuwyrazowych na ogół) oksymoronach określenie reprezentujące niebieską, doskonałą miarę rzeczy należy zaakcentować mocniej: więc tak naprawdę święty, a nie złodziej; dobry, a nie głupiec; modlitwy, a nie uczty; marność, a nie chwała ani piękno; błąd, nawet jeśli płynący z miłości, itd. Podstawowe funkcje tych retorycznych figur łatwo odgadnąć. Podnosząc - zgodnie z kanonami epoki - stylistyczne walory wykładu, miały zarazem zwracać uwagę odbiorców, niekiedy nawet poruszać ich i zdumiewać, w pierwszej kolejności po to, by wzbudzić refleksję nad ową zasadniczą, wyrażoną w samej strukturze każdej z nich różnicą: niemożliwą do zasypania przepaścią dzielącą niebo i ziemię. Paradoksalne wyrażenia odniesione bezpośrednio do głównego bohatera (takie

${ }^{73} \mathrm{VA} \mathrm{I} / \mathrm{B}$, c. 30, s. 66 (=Cc, f. 92v); VA I/C, c. 30, s. 84.

${ }^{74}$ VA I/A, c. 30, s. 46. Tak też J. Hoffmann, VA, s. 49 (Aq, f. 118rb).

75 To, że stanowi powtórzenie (wcześniej mowa, że święty „extendit manus in modum crucis", VA I/A, c. 30, s. 46), nie musi przemawiać przeciw niej. Okoliczność ta mogła zachęcać do zmiany tekstu.

${ }^{76}$ Zob.np.J.W.Góra, op.cit., s. 120 nn.; W.Berschin, op. cit., s. 167 n.i przyp. 494; M.Miladinov, Hermits Murdered by Robbers: Construction of Martyrdom in Ottonian Hagiography, „Annual of the Department of Medieval Studies at Central European University" 6, 2000, s. 9-21, tu s. 15 (〈http://www.scribd.com/doc/140667450/Annual-Medieval-Studies〉 [dostęp: 10 VII 2013]). Inny jeszcze sens upadku krzyżem widzi S. Kwiatkowski,op.cit., s. 35.

77 "qui crucem, quam [--] animo portauit, tunc eciam manibus et toto corpore complexus est", VA I/A, c. 30, s. 46 n.

${ }^{78}$ Wątpliwości związane z lekcją „felici lapsu” nie mogą stanowić argumentu w dyskusji nad pierwszeństwem lekcji Aq (por. wyżej: przyp. 19 i s. 430, niżej: przyp. 87). Upodobaniu hagiografa do podobnych oksymoronów tak czy inaczej trudno przeczyć, a hipotezę „kongenialnej poprawki” trzeba traktować jako wyjątek i ostateczność. 
jak „święty złodziej” czy „dobra głupota”) podkreślały jednocześnie jego odmienność, nieprzystawalność do doczesnych standardów, a więc przynależność do sfery ducha, innymi słowy: świętość. Nie oznacza to jeszcze, że tak uporczywie i spektakularnie zderzając ze sobą oba porządki, hagiograf nie mógł myśleć o innym także przesłaniu...

W każdym razie, nie poprzestał wcale na oksymoronach opartych na opisanym schemacie. Pozostałe jego paradoksy nie stanowią grupy tak jednorodnej formalnie, toteż trudno o ich spójną systematykę. Większość wiąże się, niechby pośrednio, z osobą lub działalnością głównego bohatera.

W cytowanej już opowieści o dzieciństwie Sławnikowica autor umiejętnie posłużył się hiperbolą o strukturze prostej kontradykcji. Choroba chłopca miała się objawić w sposób przerażający: brzuch urósł większy od całego ciała ${ }^{79}$. Niecodzienne spostrzeżenie zainspirowane może lekturą Lukana doprowadza opis rzeczywistości do granicy nonsensu ${ }^{80}$. Sprzeczność logiczna (część większa od całości) pozostaje przy tym w czytelnym związku z niepokojącą treścią wywodu: podkreśla radykalny kryzys naturalnego ładu, uzmysławiając powagę sytuacji. Wspomniana w następnym zdaniu groźba śmierci dziecka zyskuje dzięki temu na realizmie, a opisane dalej ocalenie na cudowności.

O tym, że Wojciech był najwłaściwszym kandydatem na biskupstwo, przekonuje historia uwolnienia opętanego. W katedrze praskiej, w dniu elekcji (zanim jej wynik stał się wszystkim wiadomy), opuszczając ofiarę, potężny demon miał wyznać, że boi się nowego biskupa. Jak się niebawem okazało, wybór padł właśnie na Wojciecha ${ }^{81}$. Banalny charakter anegdoty kazałby może przejść do porządku nad jej na wskroś paradoksalną wymową, gdyby nie fakt, że hagiograf wyraźnie tę ostatnią zaakcentował. W zakończeniu jako powód składanych Bogu dziękczynień wskazał nie co innego, jak owo zaskakujące qui pro quo: o wyborze świętego oznajmił zły duch. Przy okazji pokusił się nawet o kolejny, tym razem pospolity oksymoron, zaznaczając, że demon działał „chcąc i nie chcąc"82.

79 "Cerneres namque infantuli corpusculum subita magnitudine excreuisse, et pre nimia inflatione uentrem toto corpore maiorem", VA I/A, c. 2, s. 5. Tak też J. Hoffmann, VA, s. 33 (Aq, f. 103rb); VA I/B, c. 2, s. 52. W Cc, f. 88r, paradoks zmienił się w pospolity nonsens: „Cerneres namque paruum corpusculum subita magnitudine toto corpore maior esse". Na Monte Cassino fragment przeredagowano, usuwając sprzeczność, VA I/C, c. 2, s. 72. Jako hiperbolę zidentyfikował już sformułowanie hagiografa Oldřich Králík, op. cit., s. 121.

${ }^{80}$ Por. „tumor toto iam corpore maior”, Lucain, La guerre civile (La Pharsale), t. 2, wyd. A. Bourgery, M. Ponchont, Paris 1948, lib. 9, 1. 793, s. 166.

${ }^{81}$ VA I/A, c. 7, s. 11 n.

82 "Concurrunt populi cum clero, glorificantes et gratias agentes Domino, quia uolens nolensque nequam spiritus confessus est electionem illius", ibidem, s. 12. Bez 
Duszpasterskie wysiłki Wojciecha w pierwszym okresie urzędowania na biskupstwie przyniosły mu srogie rozczarowanie. Perfidii Czechów autor nadaje wymiar prawdziwie paradoksalny: „żywieni niebieskimi dobrami napełniali się mętami grzechów" "33. Pożyczona od Kasjodora (który w Komentarzu do Psalmów pisał tak o Żydach) ${ }^{84}$, kuriozalna obserwacja nie służy w Żywocie jedynie za retoryczną dekorację. Stanowi element składowy dłuższego wywodu uzasadniającego kontrowersyjną decyzję bohatera o porzuceniu urzędu. Początkowa część tej argumentacji okazuje się paradoksalna również w warstwie fundamentalnej: referowane okoliczności zdają się przeczyć naturalnemu porządkowi rzeczy. Hagiograf przekonuje bowiem (m.in. z pomocą przytoczonej frazy), że wzorowa posługa biskupia przynosiła skutek odwrotny od zamierzonego: Czesi nie pozostawali obojętni, lecz nurzali się w grzechach „tym uporczywiej”" ${ }^{\text {. Jest to }}$ rodzaj retorycznej pułapki: kto uzna prawdziwość tej przesłanki, musi przyznać, że decyzja o opuszczeniu Pragi - którą autor szerzej jeszcze uzasadnia - była usprawiedliwiona ${ }^{86}$.

W klasztorze na Awentynie czekał świętego (a na pewno czeka czytelników Żywota) nowy paradoks. Obarczono go tutaj zadaniem dostarczania

istotnych różnic: J. Hoffmann, VA, s. 36 (Aq, f. 105ra-rb); VA I/B, c. 7, s. 54; VA I/C, c. 7, s. 74. Por. H. G. Voigt, op. cit., s. 26.

${ }^{83}$ „Nouo quippe modo cum essent cęlestibus bonis pasti, peccatorum fecibus explebantur", VA I/A, c. 12, s. 17. Tak też J. Hoffmann, VA, s. 38 (Aq, f. 106va). Por. H. G. Voigt, op. cit., s. 27. Cytowany przekład w części tylko polega na ŻW I (K. A.), s. 44. Pozostałe redakcje zamiast „nouo quippe” mają „nouoque”, VA I/B, c. 12, s. 56 (=CC, f. $89 \mathrm{v}$ ); VA I/C, c. 12, s. 76. Ta błaha na pozór różnica nie zasługiwałaby na wzmiankę, gdyby nie to, że lekcja „nouoque” jest doskonale zgodna z tekstem Kasjodora, z którego pochodzi cała fraza (zob. przyp. następny). Sama jedna taka drobnostka nie dowodzi oczywiście istnienia niezachowanej, pierwotnej redakcji utworu. Chcąc obstawać przy tezie J. Frieda (który redakcję B wywodzi po prostu od A), należałoby jednak przyjąć, że rkp. redakcji A wykorzystany przez redaktora B różnił się od zachowanych (miał lepszą, przejętą od Kasjodora lekcję „nouoque”). Sam J. Fried (op. cit., s. 246, przyp. 43, s. 260 n.) uciekł się - z innych powodów - do podobnego wyjaśnienia, utrzymując, że redaktor B posługiwał się nieznanym rękopisem redakcji A z grupy IV (także tłumacząc relacje $C$ względem B, przyjął istnienie niezachowanego rękopisu, ibidem, s. 242, przyp. 30, s. 247, 249, 253 i przyp. 64, s. 262).

84 „nouoque modo bonis caelestibus pasti, malorum faecibus explebantur”, Magni Aurelii Cassiodori Expositio psalmorum, wyd. M. Adriaen, Turnholti 1958, CCh SL, t. 97-98 (dalej: Kasjodor, Expositio), in Ps 16,14, s. 149. Zapożyczenie zidentyfikował C. Gaşpar, VA, s. 124, przyp. 4.

${ }^{85}$ ŻW I (K.A.), s. 44; VA I/A, c. 12, s. 17: „illi eo arcius se in omni peccato obligare non cessant” (podkr. moje - S.W.); F. Lotter, op. cit., s. 27. „Skutek dokładnie odwrotny od zamierzonego" przypisuje wysiłkom Wojciecha Kaspar Elm, Święty Wojciech z Pragi - mnich, biskup, misjonarz i męczennik, w: Milenium synodu - zjazdu gnieźnieńskiego, red. J. Kłoczowski, C. Pest, W. Polak, Lublin 2001, s. 9-27, tu s. 15. Tymi słowy zdaje się jednak oddawać rzeczywisty przebieg zdarzeń, a nie analizowane tu kategorie opisu.

${ }^{86}$ Zob. na szerszym tle S. Wieczorek, op. cit., s. 449 n. 
współbraciom wina i wody, czego na skutek diabelskich ingerencji, ku wielkiemu swemu zawstydzeniu, często nie był w stanie dokazać. Pewnego razu przydarzyła mu się jednak „przeciwność najpomyślniejsza” („prosperrima aduersitas”): niesione przezeń naczynie z winem, wylądowawszy po raz nie wiadomo który na ziemi, miast jak zwykle roztrzaskać się, zrządzeniem Najwyższego ocalało ${ }^{87}$. Oksymoron pochodzi z cytowanej już pracy Kasjodora, który określił tym mianem tarapaty, jakie Bóg zsyła na grzeszników, by sprowadzić ich ze złej drogi ${ }^{88}$. Do historii Wojciecha taki kontekst nie pasuje. Tak samo jak przemyślenia Grzegorza Wielkiego, wywodzącego - z pomocą podobnych sformułowań - że przeciwności bywają pożyteczne, ponieważ chronią przed pychą ${ }^{89}$. Hagiograf pożyczył z pierwowzoru same tylko słowa. Wcześniejszych porażek bohatera za pomyślne najwyraźniej nie uważał. Ta jedna okazała się wyjątkiem dlatego, że - jak trzeba się domyślać - co do skutku nie ziściła się, przeciwnie: stała się okazją dla Boskiej interwencji i triumfu pokornego nosiwody. Oksymoron nie został wprawdzie zbudowany na zasadzie zderzenia porządków, ale stanowi w pewnym sensie jego rezultat.

${ }^{87}$ „Audit a longe pater monasterii cunctique fratres per ordinem, quomodo labitur ille heros, nescientes, quia hunc casum prosperrima aduersitas comitaretur", VA I/A, c. 17, s. 25 n. Oksymoron dostrzegli już J. Karwasińska (VA I, wstęp, s. XXXVII) i O. Králík (op. cit., s. 124). W rękopisach Ll, $\mathrm{Rv}_{2}$, Ut i Aq zastąpiono go słowami: „felix comitaretur eventus", VA I/A, c. 17, s. 26, przyp. b-d; J. Hoffmann, VA, s. 42 (Aq, f. 109ra), 72. J. Hoffmann (idem, VA, s. 144) uznaje tę ostatnią lekcję za lepszą. Pogląd ten nie da się utrzymać. Przeczy mu zasada lectio difficilior, ewidentna skłonność hagiografa do retorycznych paradoksów, wreszcie fakt, że „prosperrima aduersitas” to zapożyczenie z dobrze znanego mu źródła (zob. przyp. następny). Słusznie więc C. Gaşpar (idem, VA, s. 140) pozostawił oksymoron w tekście. Por. VA I/B, c. 17, s. 60 (bez zmian); VA I/C, c. 17, s. 78 (paradoks usunięty).

88 Por. Kasjodor, Expositio, in Ps 34,6, s. 307. C. Gaşpar (idem, VA, s. 140, przyp. 5) zachowuje powściągliwość i konstatuje tylko identyczność sformułowania. Przypadkowa koincydencja nie wydaje się jednak prawdopodobna. Przemawia przeciw niej oryginalny charakter wyrażenia i ślady lektury dzieła Kasjodora widoczne w innych ustępach Żywota, zob. C. Gaşpar, VA, s. 124, przyp. 4, s. 140, przyp. 3. Do zapożyczeń wskazanych przez tego badacza dodać należy: „diuinis legibus adue rsum ire omnibus modis festinarunt”, VA I/A, c. 12, s. 17; por., praedicationibus sanctis aduersum ire modis omnibus festinabant", Kasjodor, Expositio, in Ps 88,52 , s. 819 (podkr. moje - S.W.). Por. też: „uelut castissima turtur”, VA I/A, c. 20, s. 31 ; „Turtur uero abstinentiae moderatione castissimus est”, Kasjodor, Expositio, in Ps 83, 4, s. 769 (choć niepokoi to, że wzmianki różni rodzaj gramatyczny rzeczownika turtur, por. A. Kolberg, op. cit., s. 582; H. G. Voigt, op. cit., s. 31). W kontekście podobnym jak u Kasjodora „prosperrima aduersitas” występuje u Brunona z Kwerfurtu, Vita Quinque Fratrum Eremitarum [seu] Vita uel Passio Benedicti et Iohannis sociorumque suorum auctore Brunone Querfurtensi, wyd. J. Karwasińska, Warszawa 1973, MPH n.s., t. 4, cz. 3 (dalej: VQF), c. 22, s. 73.

${ }^{89}$ S. Gregorii Magni Moralia in Iob, wyd. M. Adriaen, Turnholti 1979-1985, CCh SL, t. 143, 143A, 143B, lib. 8, 10, 20, s. 396 n.; lib. 26, 45, 82, s. 1328. 
Interwencja niebios łamie reguły wydanego na pastwę diabła doczesnego świata. Tym samym wywraca też do góry nogami przyczynowo-skutkową logikę śmiertelnych, którą - co znamienne - autor postarał się uobecnić w dość czytelnie zasugerowanych oczekiwaniach opata i mnichów. Zaznaczywszy, że słysząc odgłos upadku współbrata, nie byli świadomi cudownego finału, nie musiał już tłumaczyć, że spodziewali się kolejnej katastrofy.

Również następna anegdota z klasztornego okresu biografii Wojciecha otrzymała paradoksalną pointę. Dokonany za sprawą świętego cud polegał na tym, że pewna szlachetna niewiasta, która od lat nie jadła chleba, ponownie go skosztowała. „Odtąd więc - głosi ostatnie zdanie historii - przyjmowała zwykły pokarm i opowiadała rzymianom, że zdarzyła się jej rzecz osobliwa" ${ }^{90}$. Hagiograf - co przekład trochę zaciera dobiera i porządkuje słowa z niewątpliwą premedytacją. To, co wszystkim wspólne, pospolite („cibum commune”) łączy jednym pociągnięciem pióra z nadzwyczajnym („res noua”). Tak, by uzmysłowić czytelnikom niemożliwą na pozór zamianę przeciwieństw: dzięki świętemu - a ściślej, dzięki przyzwanemu przezeń expressis verbis Chrystusowi - kobieta doświadcza niezwykłego (tj. cudu), wracając do tego, co najzwyklejsze (tj. diety typowej dla ogółu śmiertelników). Owa niecodzienność codziennego zmusza „zdrowy” rozsądek odbiorców do ponownej, kornej kontemplacji własnych ograniczeń.

Predylekcję autora do tego, co pozornie trudne do wyobrażenia, dokumentuje także dramatyczna historia cudzołożnicy, którą Wojciech, po powrocie na biskupstwo, daremnie usiłował ocalić od kary. Być może hagiograf dyskretnie droczy się z naiwną logiką prostaczków już wtedy, gdy opisuje, jak bohater, pragnąc „uwolnić” nieszczęsną od prześladowców, ,zamknął” ją w klasztorze. Dziwnym bowiem trafem oba te na pozór przeciwstawne pojęcia znalazły się w tekście tuż obok siebie ${ }^{91}$. Kapitalny przykład literackiego paradoksu przynosi przecież dopiero finał opowiastki. Łaknący męczeństwa Wojciech staje bezbronny naprzeciw żądnych krwi napastników. Nieoczekiwanie, zamiast spodziewanych razów miecza czy włóczni otrzymuje sztych zadany całkiem innym orężem. Jeden z intruzów, wyjątkowo nikczemny, wykazuje się - rzecz osobliwa -

${ }^{90}$ ŻW I (K.A.), s. 57; „Exhinc ergo communi cibo usa, rem nouam sibi contigisse ciuibus narrat”, VA I/A, c. 17, s. 26. Tak też (pomijając ortografię) J. Hoffmann, VA, s. 42 (Aq, f. 109rb); VA I/B, c. 17, s. 60; VA I/C, c. 17, s. 79.

${ }_{91}$ „Volens autem de illorum manibus mulierem liberare, clausit eam in monasterio" (podkr. moje - S. W.), VA I/A, c. 19, s. 29; por. J. Hoffmann, VA, s. 43 (Aq, f. 109vb). Czasowniki sąsiadują ze sobą w większości rękopisów, także innych redakcji, por. VA I/B, c. 19, s. 61; VA I/C, c. 19, s. 79. 
rzadkim etycznym rozeznaniem ${ }^{92}$. Przejrzawszy zamysły biskupa, występuje - qui pro quo! - z ujętym w formę zaskakującego paradoksu moralnym pouczeniem: „Błądzi z pewnością ta świętość, która chce naszego grzechu"93. Odarta z kontekstu, anegdota mogłaby zakrawać na humoreskę (perfidia grzesznika każe mu powstrzymać się od grzechu, którego święty w swej pobożności pragnie), ale na pewno nią nie jest. Złoczyńca grozi następnie zgładzeniem rodziny biskupa (co nie było wszak pozbawione odniesień do tragicznej rzeczywistości) ${ }^{94}$. Paradoksalne stwierdzenie o świętości łaknącej (cudzego) grzechu, na które Wojciech - tak jak na padające za chwilę groźby - nie odpowiada, na pewno nie służy więc powierzchownej retorycznej zabawie. Co nie znaczy, że jego interpretacja wydaje się prosta. W zachowaniu świętego dostrzeżono - uwypuklone przez autora z pomocą sformułowań ewangelicznych - analogie do Pasji $^{95}$, a w przemowie szubrawca - drwiący, szyderczy ton ${ }^{96}$. Najprawdopodobniej, zjadliwa drwina stanowi jedyny istotny sens przytoczonego zdania: Wojciech zostaje okrutnie wyszydzony, okazując się i w tym także podobny do Chrystusa (który nota bene również ani słowem nie odpowiadał prześmiewcom $)^{97}$. Treść obelżywej przemowy jako jawnie niesprawiedliwa (przypisywać komuś tak świętemu egoizm!) ${ }^{98}$ nie zasługiwałaby w tej sytuacji na głębszą refleksję, obnażając jedynie cynizm złoczyńcy. $\mathrm{Z}$ drugiej strony, paradoksalna teza intryguje: zdaje się trafnie charakte-

92 Por. M. Sosnowski, op. cit., s. 94.

93 ŻW I (B.K.), s. 63 (tu jednak: „taka świętość”); „Errat pro certo haec sanctitas, quę nostrum uult fieri peccatum", VA I/A, c. 19, s. 30. Tak też J. Hoffmann, VA, s. 43 (Aq, f. 110ra); VA I/B, c. 19, s. 61. Por. VA I/C, c. 19, s. 80 (paradoks usunięty). Por. M. Sosnowski, op. cit., s. 94 n. (także o możliwych motywacjach redaktora C). Podobny chwyt retoryczny hagiograf zastosował, referując ostateczną, wrogą Wojciechowi odpowiedź Czechów: „Agnoscimus, ingeminant, quid sub colore piętatis mendosum tinniat hęc sanctitas", VA I/A, c. 26, s.39. Mimo zbieżności (kontekst, odniesione do świętego słowa „hęc sanctitas”, ironia), tym razem trudniej mówić o paradoksie: mowa zależna nazbyt akcentuje subiektywizm opinii, której fałsz wydaje się oczywisty.

${ }^{94}$ VA I/A, c. 19, s. 30.

${ }^{95}$ Najpełniej W. Berschin, op. cit., s. 165 (ze wskazaniem na Mt 26,30; Łk 22,48; J 18,8).Zob. też H. G. Voigt, Adalbert von Prag. Ein Beitrag zur Geschichte der Kirche und des Mönchtums im zehnten Jahrhundert, Westend-Berlin 1898, s. 87; S. Haarländer, Vitae episcoporum: eine Quellengattung zwischen Hagiographie und Historiographie, untersucht an Lebensbeschreibungen von Bischöfen des Regnum Teutonicum im Zeitalter der Ottonen und Salier, Stuttgart 2000, s. 391, przyp. 72.

${ }_{96}$ T. Michałowska, Średniowiecze, Warszawa 1995, s. 81; W. Berschin, op. cit., s. 165; S. Haarländer, op. cit., s. 391.

${ }^{97}$ Por. Mt 26,67-68; 27,27-31.39-44; Mk 14,65; 15,16-20.29-32; Łk 22,63-64; 23,11.35-37; J 19,2-3.

${ }^{98} \mathrm{~W}$ innym miejscu autor wprost zapewnił, że w marzeniach o wiecznym szczęściu święty biskup nie był egoistą, VA I/A, c. 12, s. 17. 
ryzować postawę Wojciecha z jej nieuchronnymi, nawet jeśli niechcianymi konsekwencjami. M. Sosnowski dostrzegł tu przejaw poglądów bliskich św. Augustynowi, tj. krytykę tzw. heroicznego modelu męczeństwa (pojmowanego dawniej jako dowodzący osobistego męstwa akt dobro-

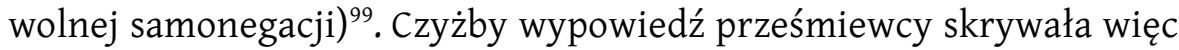
traktowaną przez autora serio, ważną prawdę o naturze śmierci męczeńskiej? W takim przypadku ostrze szyderczej krytyki nie chybiłoby bohatera - nazbyt samolubnego w marzeniu o świętości dzięki ofierze z życia i fałszywie rozumiejącego sens tej ostatniej. Tak odczytywana „świętość pragnąca grzechu" zdecydowanie wyróżniałaby się na tle innych paradoksów związanych z Wojciechem (służących na ogół zaakcentowaniu jego cnót). Sformułowanie należy na pewno do wyjątkowych pod względem warsztatowym: zwraca uwagę ścisły związek z kontekstem, umiejętne powiązanie z sytuacyjnym qui pro quo oraz ironiczny ton. Jego ewentualny literacki pierwowzór pozostaje nieznany.

W Żywocie znalazły się wreszcie paradoksy retoryczne, które ani nie odwołują się do konfliktu porządków, ani nie mają bezpośrednich związków z działalnością głównego bohatera. Jest to wprawdzie grupa nieliczna, ale godna uwagi.

Hagiograf nie byłby sobą, gdyby jego dzieło nie zaczynało się od tego rodzaju, tyleż zaskakującej, co dającej do myślenia konstatacji.Już w pierwszych zdaniach, piętnując tych słowiańskich chrześcijan, którzy trwają przy pogańskich obyczajach, dostrzega w ich położeniu osobliwe odwrócenie naturalnego porządku. Ogłasza ludźmi, ,dla których rzecz zbawienna staje się źródłem niebezpieczeństwa" ${ }^{100}$. Sens stwierdzenia rozumieć trzeba następująco: ci, którzy dostąpiwszy łaski chrztu („rzecz zbawienna”), nie odpowiedzą na nią w sposób adekwatny (zachowując pogański tryb życia), ryzykują, że w dniu sądu stanie się ona argumentem na rzecz ich potępienia („źródłem niebezpieczeństwa”) ${ }^{101}$. Lapidarna forma wypowiedzi uwydatnia paradoksalny aspekt diagnozy: życiodajny sakrament, miast niweczyć, wzmaga egzystencjalne zagrożenie! Autor i tym razem nie silił się na oryginalność. Całą frazę przepisał słowo w słowo z jednego z listów Grzegorza Wielkiego ${ }^{102}$. Raz jeszcze zignorował przy tym właściwy pierwowzorowi kontekst. Papież przez pojęcie „res salutis” rozumiał lekarstwo sensu stricto,

${ }^{99}$ M. Sosnowski, op. cit., s. 86 nn., 93 n.

100 „quibus causa periculi fit res salutis”, VA I/A, c. 1, s. 3. Tak też J. Hoffmann, VA, s. 33 (Aq, f. 102vb); VA I/B, c. 1, s. 51; VA I/C, c. 1, s. 71 (pomijając ortografię). Por. H. G. Voigt, Der Verfasser, s. 26.

101 Por. S. Kwiatkowski, Powstanie i kształtowanie się chrześcijańskiej mentalności religijnej w Polsce do końca XIII w., Warszawa-Poznań-Toruń 1980, s. 47.

${ }_{102}$ C. Gaşpar, VA, s. 96, przyp. 3. 
które podane przedwcześnie (jako niegotowe), zamiast pomagać naraża chorego na niebezpieczeństwo. Z pomocą takiej medycznej analogii krytykował nieodpowiednich, niedojrzałych kandydatów do godności biskupiej ${ }^{103}$. Hagiograf skorzystał z pożyczonych słów, by wypowiedzieć się na zupełnie inny temat. Nie znaczy to, że samą jego refleksję wolno uznać za oryginalną. Przeciwnie, ją również - rzecz doprawdy znamienna - zawdzięczał najprawdopodobniej Grzegorzowi Wielkiemu. Problem chrześcijan, którzy nie wyrzekli się pewnych praktyk pogańskich, trapił bowiem także i tego autora. „Oby sakrament świętego chrztu - pisał tonem przygany i przestrogi w innym liście - nie stał się dla nich [powodem] kary, a nie wyzwolenia"104. Zarówno u Grzegorza, jak i w Żywocie paradoks „chrztu, który może grozić wieczną karą”, odnosi się do chrześcijan praktykujących zwyczaje czy nawet kulty pogańskie, a nie wszelkich w ogóle grzeszników. Mimo to trudno chyba uciec przed pytaniem, czy hagiograf, który przywołał tę myśl na samym początku dzieła, nie adresował jej przypadkiem do ogółu odbiorców, przypominając o obowiązku należytego odwzajemnienia otrzymanego od Boga daru ${ }^{105}$.

Pod względem retorycznych niezwykłości, a na pozór jawnych aporii, wyróżnia się wreszcie ustęp Żywota poświęcony kampanii włoskiej Ottona II. Zgodnie z tenorem narracji cesarz zatwierdził wybór Wojciecha na biskupa i udzielił mu inwestytury, autor miał więc powody, by monarchę przypomnieć. Scharakteryzował go nader pochlebnie, otwarcie wynosząc ponad poprzednika. Chwalił walory bojowe, nazwał też „pod każdym względem najbardziej chrześcijańskim" ${ }^{106}$. Nawet pośród komplementów zdołał zresztą przemycić zaskakujący detal, kontrastowo zderzając wielką uirtus Ottona z jego małym wzrostem ${ }^{107}$. To, że w ogóle napomknął o wypadkach, które - także w jego ujęciu - nie całkiem pasowały do tak wyidealizowanego portretu, może wynikać stąd, że czuł się zmuszony choćby

103 S. Gregorii Magni Registrum epistularum, wyd. D. Norberg, Turnholti 1982, CCh SL, t. 140-140A, lib. 9, nr 219, s. 788.

${ }^{104}$ Ibidem, lib. 8, nr 4, s. 521.

${ }^{105}$ J. Karwasińska (ŻW I (K. A.), s. 26, przyp. 3) dostrzegła w słowach autora wyraz przekonania, że chrześcijanie nieszanujący przykazań są gorsi od pogan. W tekście brak jednak sugerowanego porównania sytuacji ochrzczonych i nieochrzczonych.

106 ŻW I (B.K.), s. 48; VA I/A, c. 8, s. 12. Na temat charakterystyki Ottona II w Żywocie zob. G. Bagemihl, Otto II. und seine Zeit im Lichte mittelalterlicher Geschichtsauffassung, Greifswald 1913, s. 25; B. Askani, op. cit., s. 25 nn., 51; W. Berschin, op. cit., s. 168; C. Gaşpar, VA, s. 114 n., przyp. 4, 6-8.

107 „in paruo corpore maxima uirtus”, VA I/A, c. 8, s. 12. Por. „maior in exiguo regnabat corpore virtus", P. Papini Stati, Thebais, wyd. A. Klotz, T.C. Klinnert, Leipzig 1973, lib. 1, 1. 417, s. 22 . 
zdawkowo zarysować tło zdarzeń. A może pragnął zarazem zdezawuować surowy osąd antycesarskiej krytyki? Tak czy inaczej, wypowiedział się bardzo paradoksalnie: nazwał Ottona „zwycięzcą i zwyciężonym”, przypisując mu żądzę odwetu za „straty [wynikłe ze] zwycięstwa”" ${ }^{108}$. Oksymorony nie zostały opatrzone żadną pointą czy wskazówką interpretacyjną, ale nie ulega wątpliwości, że tworzą razem całość i mają głębszy sens ${ }^{109}$. Nie ma podstaw, by twierdzić, że mieniąc cesarza „zwycięzcą”, hagiograf myślał jedynie o „triumfie" moralnym (jakim byłby sam trud walki z Saracenami?). Pozostaje raczej zgodzić się z Bernhardem Askanim, że trzymając się kategorii militarnych, pragnął ukazać kampanię kalabryjską 982 r. jako „połowiczne zwycięstwo” czy też „starcie nierozstrzygnięte”110. Bardzo możliwe, że pisząc o „zwycięzcy i zwyciężonym”, nawiązał do zmiennego przebiegu bitwy pod Columna Regia (dawniej lokalizowanej pod Cotrone), która przyniosła poważne straty także stronie arabskiej ${ }^{111}$. Niewykluczone, że chciał zarazem pogodzić sprzeczne oceny starcia płynące z różnych środowisk ${ }^{112}$. W każdym razie, czytelnie sugerował, że prawdziwa miara tego, co spotkało Ottona II, jest inna, niż sądziliby ci, którzy mieli go wyłącznie za „zwyciężonego"113. Tematyka niniejszych rozważań każe podkreślić sam fakt, że

108 „Idem tunc uictor et uictus pro recolligendo milite huc uenerat, uolens ultum ire damna uictorię", VA I/A, c. 8, s. 12. Tak też (pomijając ortografię) J. Hoffmann, VA, s. 36 (Aq, f. 105rb); VA I/B, c. 8, s. 54; VA I/C, c. 8, s. 74. Oba wyrażenia spostrzegł już H. G. Voigt, Der Verfasser, s. 26, 30. Zob. B. Askani, op. cit., s. 26, a zwł. W. Berschin, op. cit., s. 168. Tymczasem Augustin Kolberg (idem, Ueber den Verfasser des Lobgedichtes auf den hl. Adalbert, „Zeitschrift für die Geschichte und Alterthumskunde Ermlands” 12, 1899, s. 323-358, tu s. 325, przyp. 1) uznał „damna uictorie” (rzekomo: „Schäden der Niederlage") za przykład niedostatków prozy hagiografa.

${ }^{109}$ Nie sposób wszak mniemać, że autor chciał orzec o cesarzu coś absurdalnego.

110 B. Askani, op. cit., s. 26. Za taką militarną interpretacją przemawia wskazany przez badacza (ibidem, s. 25 n.) fakt, że sławiąc Ottona, hagiograf na pierwszym miejscu stawia jego kompetencje wojskowe. G. Bagemihl (op. cit., s. 25) uważał natomiast, że w charakterystyce cesarza akcent pada na epitet christianissimus.

${ }^{111}$ Tak sądzi C. Gaşpar, VA, s. 114, przyp. 7. O przebiegu starcia zob. K. Uhlirz, Jahrbücher des Deutschen Reiches unter Otto II. und Otto III., t. 1, Leipzig 1902, s. 177 nn. (por. Exkurs IX, s. 254-261). O miejscu bitwy: D. Alvermann, La battaglia di Ottone II contro i Saraceni nel 982, „Archivio Storico per la Calabria e la Lucania” 62, 1995, s. 115-130. Zob. też J. Banaszkiewicz, Ein Ritter flieht oder wie Kaiser Otto II. sich vom Schlachtfeld bei Cotrone rettete, „Frühmittelalterliche Studien” 40, 2006, s. 145-165 (z dalszą literaturą).

${ }^{112}$ Przynajmniej część greckiej ludności południowych Włoch najwyraźniej uważała wyprawę Ottona II za sukces, K. Uhlirz, op. cit., Exkurs IX, s. 257 (przyp. 2), 259; V. von Falkenhausen, Gregor von Burtscheid und das griechische Mönchtum in Kalabrien, „Römische Quartalschrift” 93, 1998, 3-4, s. 215-250, tu s. 232 i przyp. 83. Jeśli stanowisko hagiografa uznać za próbę pogodzenia opinii Greków i Sasów, byłby to może argument za jego awentyńskim rodowodem.

${ }_{113}$ B. Askani (op. cit., s. 26, 84) przypisuje hagiografowi po prostu chęć ukrycia porażki. Nie ma jednak pewności, czy ten ostatni oceniał wynik bitwy jednoznacznie negatywnie. 
wypowiadając się w kwestii tak delikatnej (skoro mimo podziwu dla cesarza i jego talentów bojowych nie ośmielił się nazwać go po prostu zwycięzcą, musiał zetknąć się z krytycznymi ocenami przebiegu wojny), hagiograf postanowił zrobić użytek z retorycznych paradoksów. Jakby w pozornej sprzeczności obu figur nie dostrzegał słabości, a wręcz siłę,jakby ufał w ich perswazyjną moc. Musiał w nią chyba wierzyć, skoro nie czuł się zmuszony do jakichkolwiek dodatkowych wyjaśnień. Czyżby mniemał - jeśli wolno zaryzykować śmielszą spekulację - że sama zdolność dostrzegania paradoksu, tam gdzie inni widzą rzeczy proste i oczywiste, znamionuje prawdziwego mędrca? W odróżnieniu od "strat zwycięstwa”, które wydają się pomysłem oryginalnym ${ }^{114}$, paradoksalne połączenie „zwycięzcy” ze „zwyciężonym" posiadało tradycję literacką sięgającą czasów antycznych ${ }^{115}$. Nie udało się jednak odnaleźć innego źródła, w którym pojawiłoby się w podobnym kontekście.

Omówiony zespół wzmianek aż nadto chyba dobitnie ilustruje zaanonsowaną na wstępie predylekcję twórcy Żywota do epatowania odbiorców tym, co na pierwszy rzut oka sprzeczne, niemożliwe, a przynajmniej trudne do pomyślenia. Źródeł tej pasji szukać trzeba przede wszystkim na kartach jego lektur. Hagiograf wydaje się w tym względzie wiernym uczniem dawnych mistrzów, zwłaszcza Kasjodora i Grzegorza Wielkiego (od których przepisał nawet kilka gotowych zaskakujących sformułowań $)^{116}$. Upodobanie tego rodzaju nie było czymś niespotykanym także w czasach mu współczesnych ${ }^{117}$. W niemałym stopniu podzielał je np. Bruno z Kwerfurtu, który pisząc swój Żywot św. Wojciecha, wzgardził wprawdzie paradoksami poprzednika ${ }^{118}$, ale pokusił się o włas-

${ }^{114}$ W. Berschin (op. cit., s. 168, przyp. 492) wskazuje, że w historiografii rzymskiej damnum i victoria to przeciwieństwa. Por. „ne uictoriae gloriam maculent damna uictoris", Orose, Histoires (Contre les Païens), wyd. M.-P. Arnaud-Lindet, t. 2, Paris 1991, lib. 4, c. 1,12 , s. 12.

115 Zob. Sancti Pontii Meropii Paulini Nolani Epistulae, wyd. G. de Hartel, Pragae-Vindobonae-Lipsiae 1894, CSEL, t. 29, nr 24, c. 17, s. 217; nr 28, c. 1, s. 241 (por. A. Swoboda, Osoba posłańca w listach św. Paulina, biskupa z Noli, „Vox Patrum” 10, 1990, 19, s. 703-712, tu s. 709 n.); idem, Carmina, nr 27,1.340-344, s. 277; Sancti Aurelii Augustini Contra Academicos, wyd. W. M. Green, w: Aurelii Augustini Opera, cz. 2, 2, Turnholti 1970, CCh SL, t. 29, lib. $3,14,30$, s. 52.

116 O znaczeniu paradoksów w myśli Grzegorza zob. zwł. C. Straw, Gregory the Great. Perfection in Imperfection, Berkeley-Los Angeles-London 1988, s. 21 n. i passim. O retorycznym warsztacie Kasjodora por. K. Burczak, Figury retoryczne i tropy w Psalmach na podstawie „Expositio Psalmorum” Kasjodora, Lublin 2004.

117 Jak wspomniano, H.G. Voigt (Der Verfasser, s. 26 n., 30) uznał wiele oksymoronów hagiografa za typowe dla stylu Gerberta z Aurillac.

118 Kwerfurtczyk przejął tylko wyrażenie: „in paruo corpore melior [zamiast: maxima] uirtus", S. Adalberti Pragensis episcopi et martyris vita altera auctore Brunone Querfurtensi, wyd. J. Karwasińska, Warszawa 1969, MPH n.s., t. 4, cz. 2, Redactio longior (da- 
ne, również wcale liczne ${ }^{119}$. Z drugiej strony, w takiej skali zjawisko nie wydaje się czymś nagminnym ${ }^{120}$. Jak pokazuje przykład redaktora $C$, zdarzali się też pisarze niechętni podobnym retorycznym fajerwerkom ${ }^{121}$.Już samo nagromadzenie paradoksów na kartach Vita prior zasługuje więc na uwagę. Jeszcze bardziej intryguje ich funkcja i wymowa.

Nie sposób wątpić, że hagiograf żywił wspólne ogółowi piszących ambicje stylistyczne. Mnożąc efektowne „niemożliwości”, troszczył się o formalne piękno wywodu, a zarazem dowodził należytej znajomości pisarskiego rzemiosła. Podobne motywacje nie tłumaczą jednak dostatecznie kształtu jego zabiegów. Stosunkowo nieliczne z omówionych sformułowań dadzą się bowiem sprowadzić do roli powierzchownej retorycznej dekoracji służącej co najwyżej urozmaiceniu opowiadania. Kunsztowna forma zdaje się niejednokrotnie skrywać głębszą treść. Niektóre oksymorony mogłyby nawet uchodzić za rodzaj lapidarnego podsumowania, jakby pointy oddającej w niewielu słowach naczelne przesłanie danej historii (gdyby rozdziały Żywota opatrzyć nagłówkami, „, dobra głupota”, „święty złodziej” czy „,najpomyślniejsza przeciwność" świetnie nadawałyby się do tej roli). Niekiedy pozaestetyczne motywacje autora każe podejrzewać niepokojąco ostry wydźwięk wyrażeń odniesionych bezpośrednio do świętego („dobra głupota” to przykład koronny, ale również „duchowy śmiech” czy „święty złodziej” niejednego ze współczesnych przyprawiłyby chyba o lęk przed zgorszeniem „maluczkich”). Najważniejszą przesłanką pozostaje przecież ścisły

lej: VA II/RL), c. 12, s. 14; B. Askani, op. cit., s. 55; J. Starnawski, op. cit., s. 14. Przypisany przezeń Stwórcy „risus et sacer ludus” (VA II/RL, c. 11, s. 11) mimo podobieństwa pozostaje raczej bez związku z omówionym wyżej, występującym w innym kontekście oksymoronem „spiritali risu”.

${ }^{119}$ Zob. np. „uitalibus plagis”, VA II/RL, c. 3, s. 4; „sine lingua sonat”, c. 5, s. 6; „eum quoque qui non debet puniri recte condemnas", c. 10, s. 9 (na kanwie Mdr 12,15, ibidem, przyp. 39); „una salus uictis nullam sperare salutem”, c. 10, s. 10 (z Eneidy, ibidem, przyp. 43); „nullum uolens habere inimicum, nisi inimicum”, c. 11, s. 12; „cui seruire regnare est”, c. 15, s. 18 (zapożyczenie z sakramentarza, ibidem, przyp. 86); „uiuens morior”, c. 18, s. 23; „homo tibi [tj. samemu sobie] contrarius”, c. 20, s. 26; „per pacem didicit facere bellum”, „stat proximo periculo ciuitas secura”, c. 21, s. 27; „digna indigni scribimus”, c. 22, s. 28; „, bono dolo”, c. 26, s. 33; „felix uictima”, c. 32, s. 38; „amicam mortem”, c. 33, s. 39.

120 Szerzej zakrojone studia porównawcze pozostać muszą badawczym postulatem. Dla kontrastu wskazać można objętością zbliżony do Vita prior, starszy nieco Żywot św. Fridolina [BHL 3170] Baltera z Säckingen (będzie o nim mowa), w którym Iso Müller (idem, Balther von Säckingen und seine Fridolinsvita, „Freiburger Diözesan-Archiv" 101, 1981, s. 21-65, tu s. 30 (〈http://www.freidok.uni-freiburg.de/volltexte/ 5765/> [dostęp: 16 IV 2012], urn:nbn:de:bsz:25-opus-57653) dostrzegł nieliczne tylko oksymorony (podał ledwie dwa, znaczeniowo pokrewne przykłady).

${ }_{121}$ Zob. wyżej przyp. 19, 21, 37, 50, 79, 87, 93. Już H. G. Voigt (Der Verfasser, s. 39) zauważył, że rękopisy włoskie usunęły z tekstu „die feinen Kontraste im Ausdruck und Stil”. 
związek większości paradoksów z ważnymi lub przynajmniej drażliwymi tezami wywodu. Wynikałoby stąd, że swoje zaskakujące spostrzeżenia hagiograf traktował nie tylko jako retoryczne ozdobniki, lecz także jako dające do myślenia wskazówki, czasem może bez mała „argumenty”, z pomocą których podkreślał, jeśli nie wręcz uzasadniał, prawdziwość pewnych bliskich sercu twierdzeń. Wśród tych ostatnich znajdowały się przekonania rozpowszechnione czy łatwe do przyjęcia (jak to o aksjologicznej opozycji porządków lub o przekraczającej doczesną miarę osobowości Wojciecha), ale także idee kontrowersyjne, jak teza o zasadności porzucenia biskupstwa czy (połowiczna) apologia ekspedycji Ottona II. Istnieją powody, by sądzić, że przynajmniej za częścią omówionych, niecodziennych obserwacji stało inne jeszcze, nie dla wszystkich współczesnych oczywiste przesłanie.

Jak już przygodnie sygnalizowano, niektóre wypowiedzi autora w swej jawnej - zdawałoby się - sprzeczności sprawiają wrażenie wyzwania rzuconego „zdrowemu” rozsądkowi. Niezależnie od innych refleksji, podsuwają czytelnikom smutną konkluzję o dotkliwych ograniczeniach ziemskiej logiki zawodnej zwłaszcza w zetknięciu z rzeczywistością nadprzyrodzoną. Myśl - na pozór mało oryginalna - mogłaby uchodzić za przypadkową jedynie konsekwencję nagromadzenia figur retorycznych, w których naturze leży mniej lub bardziej spektakularna kontradykcja. ów sceptycyzm wobec pospolitych intelektualnych przyzwyczajeń, czy też w ogóle wobec możliwości ludzkiego rozumu, okazuje się jednak zastanawiająco zgodny ze światopoglądem autora, który - jak już zauważono w literaturze przedmiotu - zdawkowo wprawdzie, ale dość czytelnie zdołał zaznaczyć swój dystans wobec „filozofii tego świata” ${ }^{122}$.Jego stanowisko - co także skonstatowano - znajdowało się na dodatek w opozycji do poglądów części współczesnych ${ }^{123}$.

Już stosunkowo powściągliwa wizytówka, jaką hagiograf obdarzył sławnego Wojciechowego preceptora Oktryka („quidam philosophus”), musi dawać do myślenia ${ }^{124}$. Jasnej wskazówki dostarcza jednak dopiero

${ }^{122}$ H.G. Voigt, Der Verfasser, s. 14, 33 n.; R. Wenskus, Studien zur historisch-politischen Gedankenwelt Bruns von Querfurt, Münster-Köln 1956, s. 79-83; F. Lotter, op. cit., s. 19 n., 23. Odmiennie i błędnie (zob. niżej przyp. 130): B. Hamilton, The Monastery of S. Alessio and the Religious and Intellectual Renaissance of Tenth-Century Rome, w: idem, Monastic Reform, Catharism and the Crusades, 900-1300, London 1979, s. 265-310 (przedruk za: ,Studies in Medieval and Renaissance History" 2, 1965), tu s. 290 n.; P. Czartoryski, Średniowiecze, w: Historia nauki polskiej, t. 1, Wrocław-Warszawa-Kraków 1970, s. 59.

${ }^{123}$ R. Wenskus, op. cit., s. 79-83; F. Lotter, op. cit., s. 19 n., 23. Por. H. G. Voigt, Der Verfasser, s. 33 n.

${ }^{124}$ VA I/A, c. 3, s. 6; R. Wenskus, op. cit., s. 80, a zwł. F. Lotter, op. cit., s. 19. Ten ostatni popada jednak w przesadę, widząc przyganę w odniesionych do szkoły magde- 
krótki komentarz, jakim zwieńczył opowieść o edukacji bohatera (jest to - nie wolno zapomnieć - ten sam ustęp, w którym przypisał mu „dobrą głupotę"). Oświadczywszy najpierw, że Wojciech - choć nie wiadomo, jak długo pobierał nauki - był niezwykle biegły w zakresie „doczesnej filozofii” 125 , twórca Vita prior pozwolił sobie na następującą konkluzję: „Pan [tj. Bóg], myślę, dlatego kazał mu [tj. Wojciechowi] przykładać się do filozofii pochodzącej od ludzi, żeby potem łatwiej mógł wspinać się na szczyty Bożej mądrości; albo raczej za młodu miał zakosztować goryczy świata, by potem jako mąż tym chciwiej chłonąć słodycz Boga" ${ }^{26}$. Uderza na początek wyraźnie zaznaczony osobisty charakter wypowiedzi: jedyny raz w całym Żywocie autor zwraca się do czytelników w 1 os. lp. („,credo”) ${ }^{127}$. Rzecz tym bardziej rzuca się w oczy, że ledwie w poprzednim zdaniu posłużył się - to zresztą także ewenement ${ }^{128}-1$ os. 1 m. („nouimus omnes”), chwaląc uczoność bohatera jako reprezentant - skądinąd niedookreślonego - ogółu ${ }^{129}$. Wygląda na to, że tym razem przedstawia owoc przemyśleń, których „wszystkim” przypisać nie może. W jego słowach widać na dodatek pewną dozę ambiwalencji. Ziemska filozofia uznana wpierw za pożyteczne ułatwienie na drodze ku mądrości Bożej, za chwilę zaliczona

burskiej słowach „nimis crescente studio” (VA I/A, c. 3, s. 6). Nimis nie znaczy tu, jak chce uczony: „zanadto” (,allzusehr”), lecz po prostu „,bardzo”, por. „nimis uellem”, VA I/A, c. 15, s. 23. Tak np. ŻW I (B.K.), s. 44: „nauka bardzo się podniosła”.

125 „Quot annis studuit, incertum est, sed quia sęcularis philosophię sat scientissimus erat, nouimus omnes", VA I/A, c. 5, s. 9. W Aq brak słówka sat, co J. Hoffmann błędnie raczej uznał za lekcję lepszą, idem, VA, s. 35 (Aq, f. 104rb), 67, 130. Niektórzy uczeni rozumieją owo sat ograniczająco, por. np. Das Leben, tłum. H. Hüffer, s. 8: „genugsam”; H. G. Voigt, Adalbert, s. 26: „hinlänglich”; ŻW I (K.A.), s. 33: „dostatecznie”; G. Labuda, Święty Wojciech, s. 98: „dość dogłębnie”. W rzeczywistości epitet „sat scientissimus" wyraża stopień wyższy od najwyższego, por. F. Arnaldi, P. Smiraglia, Latinitatis Italicae Medii Aevi lexicon imperfectum, pars 3, fasc. 2, „Archivum Latinitatis Medii Aevi" 28, 1958, s. 50 n. (s.v. satis). Poprawnie oddają więc jego sens np. Canapariova, tłum. J. Zachová, s. 125: „velmi dobře”; C. Gaşpar, VA, s. 107: „very well-versed”.

${ }^{126}$ ŻW I (K. A.), s. 33 n.; „Quem Dominus, credo, ad hoc humanę philosophię studere uoluit, ut post diuinę sapientię montes faciliore gressu scandere posset; aut pocius seculi amara paruulus potare debuit, ut post uir factus, Dei dulcia auidiore animo hauriret", VA I/A, c. 5, s. 9. Odmianki Aq i późniejszych redakcji nie mają znaczenia dla niniejszych rozważań, por. J. Hoffmann, VA, s. 35 (Aq, f. 104rb), 59; VA I/B, c. 5, s. 53 (większe różnice w Cc, f. 88v); VA I/C, c. 5, s. 73. Wagę tej wypowiedzi hagiografa dostrzegli H. G. Voigt, Der Verfasser, s. 14, 33 n.; R. Wenskus, op. cit., s. 79-83; F. Lotter, Christliche Völkergemeinschaft und Heidenmission. Das Weltbild Bruns von Querfurt, w: Early Christianity in Central and East Europe, red. P. Urbańczyk, Warszawa 1997, s. 163-174, tu s. 166; idem, Adalbert, s. 19 n., 23. W sprawie interpretacji Bernarda Hamiltona i Pawła Czartoryskiego zob. niżej przyp. 130.

127 Spostrzegł to już H. G. Voigt, Der Verfasser, s. 33.

${ }^{128}$ Jeszcze tylko na początku tego samego rozdziału pada - nic nieznaczące „uideamus", VA I/A, c. 5, s. 8.

${ }^{129}$ Por. H. G. Voigt, Der Verfasser, s. 34. 
zostaje „raczej” w poczet „goryczy doczesności”, które jawią się jaskrawym przeciwieństwem „słodyczy”, jakimi karmi Stwórca. Autor dystansuje się więc od pierwotnej oceny, ale nie na tyle, by usunąć ją z tekstu ${ }^{130}$. Teoria literatury każe tu dostrzec figurę retoryczną: zamierzoną, dekoracyjną autopoprawkę (correctio) ${ }^{131}$. Nie oznacza to jednak, że ową niekonsekwencję należy odrzeć ze znaczenia. Jeśli wziąć pod uwagę kontekst (wspomniane unikalne „credo”) oraz intelektualny klimat epoki (o którym niżej), słowa hagiografa wydają się raczej śladem autentycznych wahań (spotęgowanych może własną rozległą erudycją w zakresie świeckiej literatury ${ }^{132}$, a przynajmniej dowodzą świadomości, iż końcowa ocena nie u wszystkich znalazłaby zrozumienie, że pierwsza, zdezawuowana następnie teza miała współcześnie grono adherentów.

Konkluzja wywodu nie pozostawia w każdym razie wątpliwości: autor zdecydowanie odróżnia „ludzką filozofię” - która oznacza najpewniej wszelką w ogóle świecką uczoność z dziedzictwem pogańskiego antyku na czele - od mądrości prawdziwej, płynącej z wiary ${ }^{133}$. Można się domyślać, że tę ostatnią rozumie zgodnie z rozpowszechnionym w środowisku monastycznym wyobrażeniem „filozofii chrześcijańskiej” (choć on sam w takim znaczeniu pojęcia philosophia nie używa) - jako doskonałą, a więc nade wszystko mniszą lub eremicką realizację chrześcijańskiego powołania ${ }^{134}$. Nieprzypadkowo „mistrzem Bożej nauki” mieni św. Nila ${ }^{135}$.

${ }^{130}$ Literatura przedmiotu tej ambiwalencji nie komentuje, por. ibidem, s. 14, $33 \mathrm{n}$. (H.G. Voigt zauważa tylko, że „świecka filozofia” nie mogła być autorowi obojętna, skoro o niej wspomniał); R. Wenskus, op. cit., s. 80; F. Lotter, Adalbert, s. 19 n., 23. B. Hamilton (op. cit., s. 290 n.) i P. Czartoryski (op. cit., s. 59), przypisując hagiografowi przekonanie o użyteczności ziemskiej wiedzy, pominęli końcową frazę jego wywodu.

131 O correctio zob. np. H. Lausberg, Retoryka literacka. Podstawy wiedzy o literaturze, Bydgoszcz 2002 (oryg. niem. 1960), s. 430 nn.

${ }_{132}$ Zob. zwł. ostatnio C. Gaşpar, (Re)claiming, s. 33, 38 n.; idem, VA, passim (przypisy do edycji). Por. np. G. Labuda, Św. Wojciech w literaturze, s. 215.

133 Zob. H. G. Voigt, Der Verfasser, s. 14, 33; R. Wenskus, op. cit., s. 80; F. Lotter, Adalbert, s. 19, 23; C. Gaşpar,(Re)claiming, s. 36; idem, VA, s. 107, przyp. 6. Ten ostatni zauważył, że „humana philosophia” i ,secularis philosophia” znaczą dla hagiografa to samo, co „studia liberalia”. Tym pojęciem posłużył się, gdy po raz pierwszy wprowadził omawiane rozróżnienie, mianowicie wskazując odmienny zakres edukacji Wojciecha w domu („,christianis inbuitur litteris”) i w Magdeburgu („pro discendis liberalibus studiis”), VA I/A, c. 3, s. 5 n.

${ }^{134}$ Por. H. G. Voigt, Der Verfasser, s. 14; F. Lotter, Adalbert, s. 19, 23 (ten badacz pisze o „wykształceniu duchowym”, względnie „teologii”). o pojęciu „filozofii chrześcijańskiej" zob. zwł. J. Leclercq, op. cit., s. 125 n.

135 „diuine artis magister”, VA I/A, c. 15, s. 22. Porównanie tej „wizytówki” z charakterystyką Brunona z Karyntii („secularibus litteris egregie eruditus”, ibidem, c. 21, s. 33) pokazuje, że w rozróżnianiu mądrości hagiograf był konsekwentny. Brunonowi, którego - jak wiadomo - skrytykował, przypisał oczywiście tę doczesną. 
Skądinąd widać, że ściśle łączy ze sobą sferę moralną i intelektualną, traktując wybory etyczne i aksjologiczne jako przesłankę dla oceny walorów umysłowych ${ }^{136}$. Co do nauk tego świata, zdaje się koniec końców powątpiewać w duchowe pożytki płynące $\mathrm{z}$ ich uprawiania ${ }^{137}$.

To w takim właśnie kontekście, mając na względzie ów, niewolny może od wewnętrznych rozterek, ale zwerbalizowany dość czytelnie dystans wobec doczesnej „filozofii”, trzeba odczytywać „głupotę” przypisaną Wojciechowi na początku tego samego rozdziału. „Bona stultitia” expressis verbis wychwala to, czym gardzą „filozofowie” tego świata. Zorientowana etycznie mądrość Boża góruje nad pozorną kompetencją ziemskiego osądu. To w intencji naprowadzenia odbiorców na tę światłą myśl hagiograf incydentalnie zastąpił „prostotę” "głupotą" i stworzył swój szokujący oksymoron. Nie zmienia on wymowy historii. Stanowi jedynie trudne do przeoczenia dopowiedzenie, które precyzyjniej identyfikuje jej naczelne przesłanie. $W$ istocie bowiem cała anegdota z dziewczyną włączona została do opowieści o edukacji Wojciecha przede wszystkim po to, by tak dosadną ilustracją jego „prostoty” vel „dobrej głupoty” - ale nie „czystości”, jak dopisał potem zwiedziony seksualnym podtekstem kopista - zrównoważyć czy wręcz przyćmić sformułowaną na końcu pochwałę jego doczesnej uczoności ${ }^{138}$. Tej ostatniej

${ }^{136}$ Ceniący doczesne skarby i splendory nazwani zostają „głupcami”, VA I/A, c. 1, s. 4. Gorszącą (stąd „gniew” świętego) propozycję mnichów z Monte Cassino Wojciech uznaje - piórem biografa - za obraźliwą dla rozumu: czuje się traktowany jak „osioł”, VA I/A, c. 15, s. 22 (o symbolicznych konotacjach zwierzęcia upewnia np. Bruno z Kwerfurtu: „Non iungas bouem cum asino [por. Pwt 22,10], hoc est sapientem cum stulto" (VQF, c. 13, s. 68), który nota bene powtarza za klasykiem: Sancti Gregorii Magni Homiliae in Hiezechihelem prophetam, wyd. M. Adriaen, Turnholti 1971, CCh SL, t. 142, lib. 2, hom. 7, c. 1, s. 315. Słusznie więc K. Elm (op. cit., s. 17), referując słowa świętego, pisze: „głupi jak osioł”). Jak wspomniano, brak aksjologicznego rozeznania hagiograf postrzega jako uchybienie moralne rodziców Wojciecha.

137 Zob. zwł. F. Lotter, Adalbert, s. 23. Por. H.G. Voigt, Der Verfasser, s. 14, 33; R. Wenskus, op. cit., s. 80 .

${ }^{138}$ Nie można się więc zgodzić z C. Gaşparem ((Re)claiming, s. 31 n., 34 nn.), który biorąc za dobrą monetę wspomniany dodatek rękopisów grupy Ib, uznał właśnie czystość świętego za naczelne przesłanie anegdoty. Niektóre argumenty uczonego pozostają w mocy (trudno np. przeczyć seksualnym podtekstom historii lub temu, że czystość to $u$ ascety i przyszłego biskupa - zwłaszcza zmagającego się z seksualnymi występkami owieczek - cnota bardzo na miejscu). Nie wyciągnął on jednak należytych wniosków ze szkolnego kontekstu i nie dostrzegł opisanego związku z ujawnionym w zakończeniu sceptycyzmem autora wobec ziemskiej nauki. Również przekonanie, że - tak daleka od sztampy - historia została ad hoc zmyślona przez hagiografa, nie wydaje się dostatecznie uzasadnione. P. Golinelli, Sant'Adalberto di Praga tra agiografia e storia, w: Il millenario di Sant'Adalberto a Verona. Atti del Convegno di studi della Biblioteca Capitolare e delle Celebrazioni cittadine, Verona, 11-12 aprile 1997, red. idem, Bologna 2000, s. 27-42, tu s. 31 n., który nie bez pewnej racji dostrzega w Vita prior synteze 
najwyraźniej nie można było świętemu odmówić ${ }^{139}$.W opinii autora świętość nie miała jednak ze starannym wykształceniem nic wspólnego (wynika to ze słów o "goryczy” ziemskich nauk). Wymagała mądrości stojącej ponad „filozofią" tego świata i raczej w opozycji do niej. Nic dziwnego, że nad inteligencją czy pojętnością bohatera hagiograf specjalnie się nie rozwodził. Nadmienił o nich wcześniej, pochlebnie, ale krótko ${ }^{140}$. Opisując lata nauki szkolnej, skupił się natomiast na tym, co ważne: na zilustrowanej sugestywnymi przykładami charakterystyce moralnej postawy Wojciecha ${ }^{141}$. Nieprzypadkowo jako powód uznania ze strony niezidentyfikowanych admiratorów przedstawił nie pilność czy postępy w nauce, lecz właśnie zachowanie podczas incydentu z dziewczyną i „tym podobne” postępki ${ }^{142}$.

W tej sytuacji nasuwa się nawet pytanie, czy wspomnianą wyżej autorską deklarację niewiedzy co do czasu edukacji świętego wolno aby na pewno interpretować - jak to się zwykle czyni - całkiem po prostu. Czy w kręgu znajomych Wojciecha, z którymi stykał się jego biograf, tego rodzaju informacja - dostępna, jak wiadomo, Brunonowi z Kwerfurtu ${ }^{143}$ - okazała się rzeczywiście nie do zdobycia? Z tego, co właśnie

biskupiego (nauka) i monastycznego (sancta simplicitas) modelu świętości, rozumie „prostotę” dość wąsko: jako „niewinność”.

${ }^{139}$ Czy dlatego, że istotnie był uczony, czy ze względu na to, że od biskupów oczekiwano wykształcenia, zob. R. McKitterick, Ottonische Kultur und Bildung, w: Otto der Große, Magdeburg und Europa, red. M. Puhle, t. 1, Mainz 2001, s. 209-224, tu s. 212, por. też S. Haarländer, op. cit., s. 271 nn. Nawet jeśli oczekiwania te dotyczyły raczej wiedzy religijnej, świecka też pewnie bywała atutem, por. P. Golinelli, op. cit., s. 31. Nieprzypadkowo chyba, pisząc o powołaniu Brunona z Karyntii na papieża, hagiograf wspomniał jego świecką uczoność (zob. wyżej przyp. 135). Z drugiej strony, faktem jest, że wśród przesłanek elekcji biskupiej Wojciecha wykształcenia nie wymienił, VA I/A, c. 7, s. 11; R. Wenskus, op. cit., s. 79.

140 „Aderat sibi discenti spiritus semper indiuiduus comes, et cucurrit diuite uena ingenium, ratio et sensus", VA I/A, c. 3, s. 7.

${ }^{141}$ VA I/A, c. 4-5, s. 7-9. Padają tu takie określenia, jak „opus suum bonum”, „bona operatio”, „omne uirtutum exercitium”. Por. P. Golinelli, op. cit., s. 31 n.

${ }^{142}$ VA I/A, c. 5, s. 8. C. Gaşpar ((Re) claiming, s. 36; por. idem, VA, s. 107) sądzi, że wspomniane dalej przez owych admiratorów Wojciechowe „humanitatis studia” znaczą to samo co „humana philosophia”, por. „O ter quaterque beatus, si hec humanitatis studia tota deuotione adimpleuerit”, VA I/A, c. 5, s. 8. Gdyby nawet tak było, z przytoczonych słów nie wynika pochwała uczoności świętego. Interpretacja badacza wydaje się skądinąd błędna, por. np. „diese menschenwürdigen Bestrebungen”, H. G. Voigt, Adalbert, s. 45; „wysiłek człowieczeństwa”, ŻW I (B. K.), s. 45. Nie stanowi dla niej oparcia zidentyfikowany przez C. Gaşpara ((Re)claiming, s. 35 n.; idem, VA, s. 106, przyp. 3) literacki pierwowzór słów hagiografa, por.Jan Kasjan, Collationes, Conlatio 2, c. 2, 3, s. 41.

${ }_{143}$ VA II/RL, c. 6, s. 6 (mowa o dziewięciu latach nauki). Pogląd G. Labudy (Święty Wojciech, s. 101), jakoby deklarowana niewiedza twórcy Vita prior „podważała” wiarygodność informacji Brunona, jest nieuprawniony. Wzmianki nie stoją w sprzeczności. 
powiedziano, wynikałoby, że na jej zdobywaniu nie musiało mu specjalnie zależeć. Mógł sobie na „incertum est” pozwolić. Nawet jeśli istotnie nie znał prawdy, zastanawia fakt, że - jak rzadko kiedy ${ }^{144}$ - zdecydował się o tym wszem i wobec oznajmić. Czyżby dawał w ten sposób wyraz programowemu désintéressement?

Niezależnie od trafności tej ostatniej, nieco może śmiałej supozycji, trudno oprzeć się podejrzeniu, że nie tylko „bona stultitia” (w dosłowności na pewno najbardziej wyrazista), lecz także niektóre inne paradoksy hagiografa wyrastają - niechby w pewnym stopniu - z krytycznej refleksji nad „filozofią" tego świata. Sformułowania oparte na schemacie zderzenia porządków przekonują wszak w części dość wyraźnie o ułomności ziemskiej, a wyższości Boskiej miary ludzi i zdarzeń. Z kolei paradoksy, których składowe dadzą się akcentować równie mocno (a więc zdają się jednakowo prawdziwe), tworząc całość o nieusuwalnej z pozoru sprzeczności, podsycają sceptycyzm wobec doczesnej „filozofii” w sposób pośredni. Epatując absurdem kontradykcji, każą wątpić w możliwości powszechnej wśród mędrców tego świata dwuwartościowej logiki. Taką wymowę najłatwiej przypisać „niemożliwościom” z opowieści o cudach („najpomyślniejszej przeciwności" i niezwykłości najzwyklejszego), które obnażają bezradność ludzkich kategorii poznawczych w obliczu bezpośredniej ingerencji Stwórcy. Ślad podobnych przemyśleń mogą też stanowić oksymorony odniesione do Ottona II. Trudno inaczej zrozumieć tę niezwykłą pewność siebie, która pozwoliła autorowi pisać o cesarzu, a może wręcz bronić go przed krytyką, z pomocą sformułowań jawnie sprzecznych.Jakby właśnie w ich sprzeczności upatrywał - spoglądając ponad głowami ziemskich „filozofów” - przejaw mądrości prawdziwej.

Wstrzemięźliwy stosunek twórcy Vita prior do nauk tego świata, ich odróżnianie czy przeciwstawianie oświeceniu płynącemu z wiary, wydać się musi na pozór czymś banalnym. Takie stanowisko miało za sobą wielowiekową tradycję ${ }^{145}$. Najważniejszy pewnie duchowy mistrz hagiografa Grzegorz Wielki także odróżniał „mądrości”. Wprawdzie analiza jego pism, na jaką stać badaczy z innej epoki, nie potwierdza, by był zasadniczo niechętny świeckiej uczoności (uważał ją za pożyteczną, bo pomocną w zrozumieniu Pisma Św.), ale niektóre jego wypowiedzi mogły sprawiać takie wrażenie ${ }^{146}$. W środowisku monastycznym, do którego pierwszy biograf

${ }^{144}$ Niewiedzę autor wyznaje otwarcie jeszcze tylko raz, pisząc o wizji św. Nila, VA I/A, c. 29, s. 44.

145 Zob. P. Riché, Edukacja i kultura w Europie Zachodniej (VI-VIII w.), Warszawa 1995 (oryg. franc. 1962), zwł. s. 91-110.

146 Zob. m.in. ibidem, s. 156-168; C. Dagens, Grégoire le Grand et la culture: de la „sapientia huius mundi” à la ,docta ignorantia”, ,Revue des Études Augustiniennes” 14, 1968, 
św. Wojciecha na pewno należa1 ${ }^{147}$, sceptycyzm wobec świeckiej nauki usankcjonował własnym przykładem sam św. Benedykt ${ }^{148}$. Uwagi badaczy nie uszła zastanawiająca zgodność opinii hagiografa ze stanowiskiem bliskiego św. Wojciechowi Leona, opata awentyńskiego klasztoru św.św. Bonifacego i Aleksego. Ten ostatni, występując w liście do Hugona Kapeta przeciw krytykom papiestwa, otwarcie i nader wymownie uzasadniał wzgardę dla wyliczonych kolejno: Platona, Wergiliusza, Terencjusza oraz ,innych filozofujących bydląt". Jako chwalebne przeciwieństwo traktował za to wykształcenie „w naukach apostolskich i ewangelicznych"149.

W tej sytuacji, pobrzmiewająca w słowach Wojciechowego biografa nuta niezdecydowania oraz niezwyczajne mu sygnalizowanie subiektywnego charakteru wypowiedzi (jakby nie chodziło o rzecz powszechnie wiadomą) mogłyby się wydać zaskakujące, a proponowana interpretacja niektórych jego paradoksów - ryzykowna. Po co przekonywać o oczywistościach w sposób tak subtelny? Pewne różnice w poglądach uznanych autorytetów nie tłumaczą chyba takich wahań i chowania się za retorycznymi sprzecznościami. Rzecz staje się zrozumiała, dopiero gdy przypomnieć szczególny intelektualny klimat epoki: w czasach ottońskich mądrość tego świata zyskała w osobach swych mniej lub bardziej

s. 17-26; V. Paronetto, Gregorio Magno e la cultura classica, „Studium” 74, 1978, s. 665-680; C. Moreschini, Gregorio Magno e la cultura classica, „Studi Classici e Orientali” 56, 2010, s. 87-107. Wielu średniowiecznym odbiorcom znającym pisma papieża tylko wyrywkowo niuanse jego myśli dyskutowane przez uczonych siłą rzeczy nie były dostępne. Już Fedor Schneider (idem, Rom und Romgedanke im Mittelalter. Die geistigen Grundlagen der Renaissance, München 1926, s. 153 n.) wskazał jako źródło bliskiego Janowi Kanapariuszowi (którego uważał za autora Vita prior) i mnichom od św.św. Bonifacego i Aleksego ideału „duchowej prostoty” - właśnie Grzegorza Wielkiego (konstatował zarazem, że nie byli gotowi tego ideału realizować).

147 Zob. ostatnio C. Gaşpar, VA, preface, s. 91 n.

${ }^{148}$ Już na wstępie 2 księgi Dialogów Grzegorz Wielki informuje, że Benedykt porzucił doczesne studia, i sugestywnie uzasadnia tę decyzję. Postawę świętego kwituje znanym paradoksem: „scienter nescius et sapienter indoctus”, Grégoire le Grand, Dialogues, wyd. A. de Vogüé, t. 2, Paris 1979, Sources Chrétiennes, t. 260, lib. 2, prol., 1, s. 126. Por. J. Leclercq, op. cit., s. 18 n.; P. Riché, op. cit., s. 60, 106, 125 n.; C. Dagens, op. cit., s. 25.

${ }^{149}$ Brief des Abtes Leo an König Hugo von Frankreich, wyd. E.-D. Hehl, C. Servatius, MGH Concilia, t. 6, cz. 2, Hannoverae 2007, nr 48, s. 488 (wydawcy wskazują, że wyrażenie „pecudes philosophorum” pochodzi od św. Hieronima). o liście zob. H. Zimmermann, Abt Leo an König Hugo Capet. Ein Beitrag zur Kirchengeschichte des 10. Jahrhunderts, w: Festschrift Karl Pivec, red. A. Haidacher, E. Mayer, Innsbruck 1966, s. 327-343. W badaniach nad św. Wojciechem i Vita prior poglądy Leona już przywoływano, zob. zwł. S. Zakrzewski, Opactwo benedyktyńskie śś. Bonifacego i Aleksego na Awentynie w latach 9771085, RWHF PAU 45, 1903, s. 38-124, tu s. 73 nn.; H. G. Voigt, Der Verfasser, s. 33 (uczony uważał Leona za jednego z kandydatów na autora Vita prior, ibidem, s. 17 nn., 40); R. Wenskus, op. cit., s. 82 n. 
zaawansowanych adeptów wpływowe grono sympatyków i obrońców. Nie ma tu miejsca na szerszą charakterystykę ówczesnej nauki czy choćby bliższą prezentację jej luminarzy, z Gerbertem z Aurillac, wspomnianym Oktrykiem czy Abbonem z Fleury na czele ${ }^{150}$.Zakres i poziom rozumianej ściśle filozofii tamtych czasów nie musi dziś imponować ${ }^{151}$. Czytając jednak znaną relację Richera z Reims o nie mniej znanej debacie Gerberta z Oktrykiem, trudno przeczyć przynajmniej - niechby nawet powierzchownej tylko fascynacji części współczesnych ziemską, a więc także pogańską (z punktu widzenia jej źródeł i mistrzów) uczonością ${ }^{152}$.

Dowodów na to, że sceptycyzm, z jakim odniósł się do niej twórca Vita prior, budził wówczas kontrowersje, i to również w środowisku monastycznym, nie trzeba zresztą szukać daleko. Przekonuje o tym lektura Żywota św. Wojciecha pióra Brunona z Kwerfurtu. Zmiany, jakie w tym właśnie względzie wprowadził on do tekstu poprzednika, wskazują, że zgoła odmiennie oceniał doczesną naukę ${ }^{153}$. Bruno nie tylko wylewniej sławił Oktryka, którego porównał do Cycerona ${ }^{154}$, lecz także gruntownie przerobił opowieść o edukacji bohatera. Anonsując przedmiot nauczania w szkole magdeburskiej, użył na określenie „sztuk wyzwolonych” terminu: „septem panes sapientię" 155 . Historię z dziewczyną - a wraz z nią wzmianki o „świętej prostoduszności” i „dobrej głupocie” - pominął milczeniem ${ }^{156}$. W finale, zamiast zderzać ze sobą dwie mądrości, wolał przeciwstawiać „dzień wiedzy” „gęstej nocy ignorancji”, by dalej — okrasiwszy tekst wersetem z Wergiliusza - wywodzić jeszcze o „słodkim

150 O nauce i kulturze X w. zob. np. J.J. Contreni, The Tenth Century: The Perspective from the Schools, w: Haut Moyen Âge, s. 379-387; C. Leonardi, Intellectual Life, w: The New Cambridge Medieval History, t. 3, red. T. Reuter, Cambridge 1999, s. 186-211; R. McKitterick, op. cit. Zob. też przyp. następny.

151 Zob. C. S. Jaeger, Philosophy, ca. 950-ca.1050, „Viator” 40, 2009, 1, s. 17-40. Por. też A. Kijewska, Czasy świętego Brunona z Kwerfurtu okiem historyka filozofii, w: Święty Brunon. Patron lokalny czy symbol jedności Europy i powszechności Kościoła, red. A. Kopiczko, Olsztyn 2009, s. 73-93.

152 Richeri Historiarum libri IV, wyd. H. Hoffmann, Hannoverae 2000, MGH SS, t. 38, lib. 3, c. 55-65, s. 199-205. Z nowszych prac o dyspucie zob. C. S. Jaeger, Gerbert versus Ohtric: Spielregeln einer akademischen Disputatio im 10. Jahrhundert, w: Spielregeln der Mächtigen. Mittelalterliche Politik zwischen Gewohnheit und Konvention, red. C. Garnier, H. Kamp, Darmstadt 2010, s. 95-120. Por. też sugestywny wywód Abbona z Fleury, który przytacza Pierre Riché, Abbon de Fleury. Un moine savant et combatif (vers 950-1004), Turnhout 2004, s. 97.

${ }^{153}$ R. Wenskus, op. cit., s. 79 nn. Zob. też F. Lotter, Adalbert, s. 19 n., 23, 50 n.; idem, Christliche, s. 166. Poniższe uwagi opierają się na spostrzeżeniach tych badaczy.

${ }^{154}$ VA II/RL, c. 5, s. 5 n. Zob. też J. Starnawski, Über die Anfänge der polnisch-lateinischen Hagiographie, „Mittellateinisches Jahrbuch” 24/25, 1989/1990, s. 457-460, tu s. 459.

155 VA II/RL, c. 4, s. 5.

${ }^{156}$ R. Wenskus, op. cit., s. 75; F. Lotter, Adalbert, s. 21. 
nektarze mądrości", jaki Wojciech zabrał ze sobą do domu ${ }^{157}$. Opisując okoliczności elekcji biskupiej, nie omieszkał dodać, że jedną z jej przesłanek była - niedostrzeżona w Vita prior - Wojciechowa ,alta scientia" ${ }^{158}$. Przebijający z tych zmian pozytywny stosunek Brunona do świeckich nauk uczeni łączą z jego edukacją w Magdeburgu i wpływami gorzeańskiego nurtu reformy monastycznej ${ }^{159}$.

Jeśli wziąć pod uwagę zarysowane pokrótce okoliczności, wspomniana doza ambiwalencji i subiektywizmu widoczna w stanowisku autora starszej biografii, posługiwanie się paradoksami zamiast otwartych deklaracji przestaje dziwić. Pozostawał on co do zasady wierny tradycyjnemu, niechętnemu świeckiej nauce stanowisku. Świadom jednak toczonych współcześnie sporów i oczekiwań szerszej - niż tylko krąg podobnie myślących współbraci - publiczności, być może ulegając także wpływowi własnej, wcale nie tylko chrześcijańskiej erudycji, wolał nie stawiać sprawy aż tak ostro i jednoznacznie, jak uczynił to opat Leon.

Sceptyczna ocena nauk tego świata miała w tamtym czasie i innych zwolenników. Można się o tym przekonać, czytając spisany ok. 970 r., przez Baltera z Säckingen Żywot św. Fridolina ${ }^{160}$. Autor - identyfikowany przez część uczonych z Balderykiem, biskupem Spiry (zm. 986 lub $987)^{161}$ - już w otwierającym tekst liście dedykacyjnym adresowanym do Notkera (II) z Sankt Gallen (zm. 975) dał wyraz swemu umiłowaniu mądrości ${ }^{162}$. Jej natury z początku nie precyzował. Dopiero przedstawiając - rzekomo na podstawie dawniejszego źródła pisanego ${ }^{163}-$ koleje losu bohatera, wprowadził znane skądinąd rozróżnienie. Przypi-

157 VA II/RL, c. 6, s. 6.

158 Ibidem, c. 8, s. 7.

${ }^{159}$ R. Wenskus, op. cit., s. 82; F. Lotter, Adalbert, s. 23, 50 n.

${ }^{160}$ M. Pörnbacher, Vita Sancti Fridolini. Leben und Wunder des heiligen Fridolin von Säckingen. Beschrieben von Balther von Säckingen, Bischof von Speyer. Texte - Übersetzung Kommentar, Sigmaringen 1997 (edycja: s. 218-260). Wydawczyni przyjmuje, że tekst powstał ok. 970 r., ibidem, s. 17. Por. W. Berschin, op. cit., s. 114-117 („ok. 960-970”).

${ }^{161}$ Tak, za dawniejszą literaturą: M. Pörnbacher, op. cit., s. 5 nn.; W. Berschin, op. cit., s. 117. Inaczej sądzi Wolfgang Haubrichs, Biographie und Onomastik, w: Scripturus vitam. Lateinische Biographie von der Antike bis in die Gegenwart. Festgabe für Walter Berschin zum 65. Geburtstag, red. D. Walz, Heidelberg 2002, s. 1-23, tu s. 6-9.

162 „Ob amorem circuissem discipline” - wyjaśnił jeden z powodów swej peregrynacji, co należy chyba rozumieć w powiązaniu ze wspomnianą wcześniej „scolastica disciplina”, M. Pörnbacher, op. cit., prol., 1, s. 218 (z przekładem: „aus Liebe zur Wissenschaft”, s. 219). Sławiąc Notkera, Balter wskazał najpierw jego mądrość („doctrina sophie famosissimo”), w Sankt Gallen dostrzegał jej źródło („fons sapientie”), ibidem, s. 218.

${ }^{163}$ Ibidem, prol., 1, s. 220-222, por. s. 17 n., 92, 95; M. Goullet, rec.: Mechthild Pörnbacher, Vita sancti Fridolini. Leben und Wunder des heiligen Fridolin von Säckingen. Beschrieben von Balther von Säckingen, Bischof von Speyer. Texte - Übersetzung - Kommentar, Sigmaringen 1997, „Francia” 25, 1998, 1, s. 330-332, tu s. $331 \mathrm{n}$. 
sawszy Fridolinowi wyjątkowy pociąg do nauki „, słodkich zasobów filozofii", pośpieszył z wyjaśnieniem, że do sofistyki i sylogistyki święty odnosił się ze wzgardą, a mądrość, której łaknął, nie miała nic wspólnego z mądrością Pitagorasa i Platona, lecz pochodziła od Boga ${ }^{164}$. Hagiograf uważał, że „sapientia” filozofów i „summa sapientia” Stwórcy nie dadzą się pogodzić, kultywowanie pierwszej oznaczałoby uchybianie drugiej. W takim właśnie duchu - jako wyraz potępienia, a nie usprawiedliwienia doczesnej nauki - odczytywał werset: „wszelka mądrość od Boga pochodzi” (Syr 1,1), którym zakończył ten ustęp dzieła ${ }^{165}$. Również Balter z Säckingen odnosił się więc do świeckiej uczoności sceptycznie. Cenił wprawdzie wykształcenie i książkową wiedzę, ale - jeśli mu wierzyć - miał na myśli wyłącznie studia i lektury o tematyce religijnej ${ }^{166}$. Chociaż w jego zastrzeżeniach nie ma nic oryginalnego, sam fakt, że je sformułował, nie musi być wyłącznie topicznym przejawem wierności tradycji czy banalnym odwzorowaniem zaginionego (?) pierwowzoru. Bardzo możliwe, że stanowi świadectwo tej samej, żywej współcześnie dyskusji, która twórcę Vita prior popchnęła do zabrania głosu, ale z drugiej strony skłoniła do powściągliwości w prezentowaniu własnych racji.

Dobiegająca w tym miejscu kresu wędrówka szlakiem retorycznych paradoksów pozwala dostrzec w najstarszym Żywocie św. Wojciecha swego rodzaju przypowieść o Bożej mądrości. Tej, która ziemskim filozofom zdaje się często niedorzecznością czy „głupotą”, ponieważ reprezentując odmienny, doskonały porządek, przekracza dostępne im kategorie i kryteria oceny.Jak pisał św. Paweł: ,Jeśli ktoś spośród was mniema, że jest mądry na tym świecie, niech się stanie głupim, by posiadł mądrość. Mądrość bowiem tego świata jest głupstwem u Boga"167. Wojciech okazuje się człowiekiem, któremu doczesna uczoność nie przeszkodziła - bo w opinii biografa pomóc raczej nie mogła - by pozostać „głupim”, tj. podążyć szlakiem zakotwiczonej w wierze prostoty i pokory, na przekór rachubom, marzeniom i przyzwyczajeniom zwykłych śmiertelników ${ }^{168}$. Świadectwem tej postawy jest tylekroć powracający na kartach dzieła motyw pytania o radę ${ }^{169}$.

${ }^{164}$ M. Pörnbacher, op. cit., c. 3, s. 224-226.

165 Ibidem, s. 226.

166 Por. ibidem, s. 98. Co znamienne, analiza źródeł żywota ujawniła nieliczne tylko nawiązania do autorów pogańskich, ibidem, s. 51-70.

167 Pismo Święte Starego i Nowego Testamentu. Biblia Tysiaclecia, wyd. 3, Poznań-Warszawa 1983 (dalej: BT), s. 1294: 1 Kor 3,18-19, por. Kol 2,8. W związku z „dobrą głupotą” wersety te cytuje już M. Sosnowski, op. cit., s. 146.

168 Por. G. Labuda, Św. Wojciech w literaturze, s. 215; J.W. Góra, op. cit., s. 107, 114.

${ }^{169}$ Wskazywano już nań, komentując rozmaicie, por. A. Hauck, Kirchengeschichte Deutschlands, t. 3, Leipzig 1896, s. 247; T. Silnicki, Św. Wojciech-człowiek i święty oraz jego działalność na tle epoki, w: Święty Wojciech, 997-1947, s. 23-71, tu s. 43, 50 nn.; J.W. Góra, 
Mimo że świetnie wykształcony, Wojciech z reguły nie podejmuje ważnych decyzji sam. Najwyraźniej zdaje sobie sprawę, że znajomość ziemskiej „filozofii” nie wystarczy. Jako „bene simplex”, tj. mądry mądrością Bożą, ma w sobie dość pokory, by prosić o opinię innych ${ }^{170}$. Potrafi też uznać słuszność rady nieproszonej czy wręcz niechcianej, jak pouczenie mnichów z Monte Cassino o niebezpieczeństwie pielgrzymowania czy zakaz Wielicha wzbraniającego fałszywego samooskarżenia ${ }^{171}$. „Głupi uważa swą drogę za słuszną, ale rozważny posłucha rady" - mówi Pismo w innym miejscu ${ }^{172}$. Cytowanych tu biblijnych wersetów hagiograf nie przytoczył. Drogę prawdziwej mądrości wolał podpowiadać czytelnikom w inny sposób. To w tej właśnie intencji od czasu do czasu kłuł ich w oczy retorycznymi paradoksami. Spektakularne, czasem nawet szokujące, przynajmniej w części podsuwały one odbiorcom tę samą zbawienną prawdę o znikomości ludzkiej „filozofii” i całego doczesnego porządku. Zachęcały tym samym, by podążając w ślad za św. Wojciechem, tak jak on przekroczyć miarę tego świata.

\section{Bona stultitia. On the Meaning of Rhetorical Paradoxes in the Oldest Life of St. Adalbert}

The author of the oldest extant (so-called imperial or "A") edition of Vita prior sancti Adalberti appreciated rhetorical paradoxes, as evidenced upon those numerous occasions when he reached for concise oxymorons, such as bona stultitia, pius error, mala uenia or damna uictoriae. This stylistic predilection was quite common and it has been noticed that during the Early Middle Ages many hagiographers observed it, especially in order to emphasise opposites characteristic for their religious world outlook, and, predominantly, evocatively to oppose the divine (eternal, perfect) and the human (precarious, deformed). A considerable fragment of the paradoxes found in Vita prior also expresses this notion. Nonetheless, their author does not appear to have been exclusively a passive imitator of literary tradition. His paradoxes - only partly identified in existing publications on the subject - do not merely document his literary skill and erudition. The function they fulfill in Vita i.e. their, at times, blatant message, the link with the main protagonist, and the important theses of the argument compel us to suspect that the hagiographer attached also an extra-aesthetic significance to his paradoxes. At the very least some of them should be

op. cit., s. 114 n.; P. Licciardello, Agiografia latina dell'Italia centrale, 950-1130, w: Hagiographies. Histoire internationale de la littérature hagiographique latine et vernaculaire en Occident des origines à 1550, red. G. Philippart, t. 5, Turnhout 2010, s. 447-729, tu s. 588.

170 VA I/A, c. 12 , s. 18 n. (pyta Wielicha o sens wizji); c. 13, s. 19 (prosi o radę papieża); c. 15, s. 22 (radzi się św. Nila); c. 17, s. 25 (w klasztorze wyjawia myśli duchowym przewodnikom); c. 25, s. 37 (szuka pomocy świętych, zwierza się z planów cesarzowi).

171 VA I/A, c. 14, s. 21 ; c. 19, s. 29.

172 BT, s. 719: Prz 12,15. 
interpreted in connection with his sceptical stand towards the learnedness of the period (contrasted with the true wisdom of God).

This approach is accentuated in the titular bona stultitia and probably also in the hagiographer's other paradoxes, discreetly undermining uncritical trust in the wisdom of temporal logic. True, the critique of earthly wisdom had a long tradition, in particular in the monastic milieu, but during the Ottonian period it became the object of a controversy even, as The Life of Saint Wojciech (Adalbert) by Bruno of Querfurt demonstrates, within that particular environment. Herein lies an explanation of the fact that the hagiographer proposed to his readers an otherwise unoriginal thesis in a rather subtle manner, aggravating them with his paradoxes, and depicting St. Wojciech as endowed with the wisdom of God and not solely earthly wisdom. An analysis of some of the rhetorical figures used by the hagiographer also offers a number of important premises for research focused on a critique of the text of Vita.

Translated by Aleksandra Rodzińska-Chojnowska 